\title{
Soybean Interaction with Engineered Nanomaterials: A Literature Review of Recent Data
}

\author{
Vasile Coman $^{1}$ (D), Ioana Oprea ${ }^{1}$, Loredana Florina Leopold ${ }^{1,2}$, Dan Cristian Vodnar ${ }^{1,2}$ aD and \\ Cristina Coman $1,2, *$ (D) \\ 1 Institute of Life Sciences, University of Agricultural Sciences and Veterinary Medicine, \\ 400372 Cluj-Napoca, Romania \\ 2 Faculty of Food Science and Technology, University of Agricultural Sciences and Veterinary Medicine, \\ 400372 Cluj-Napoca, Romania \\ * Correspondence: cristina.coman@usamvcluj.ro; Tel.: +40-746-959-157
}

Received: 25 July 2019; Accepted: 2 September 2019; Published: 3 September 2019

\begin{abstract}
With a continuous increase in the production and use in everyday life applications of engineered nanomaterials, concerns have appeared in the past decades related to their possible environmental toxicity and impact on edible plants (and therefore, upon human health). Soybean is one of the most commercially-important crop plants, and a perfect model for nanomaterials accumulation studies, due to its high biomass production and ease of cultivation. In this review, we aim to summarize the most recent research data concerning the impact of engineered nanomaterials on the soya bean, covering both inorganic (metal and metal-oxide nanoparticles) and organic (carbon-based) nanomaterials. The interactions between soybean plants and engineered nanomaterials are discussed in terms of positive and negative impacts on growth and production, metabolism and influences on the root-associated microbiota. Current data clearly suggests that under specific conditions, nanomaterials can negatively influence the development and metabolism of soybean plants. Moreover, in some cases, a possible risk of trophic transfer and transgenerational impact of engineered nanomaterials are suggested. Therefore, comprehensive risk-assessment studies should be carried out prior to any mass productions of potentially hazardous materials.
\end{abstract}

Keywords: engineered nanomaterials; phytotoxicity; plant microbiota; soybean

\section{Introduction}

Nanotechnology, together with molecular biology and information technology, has brought new insights into the understanding of our life on Earth [1]. Products of nanotechnology, such as engineered nanomaterials (ENMs), are one of the new and exciting discoveries of the past century. ENMs, which are materials with dimensions in the range where biological interactions are imminent, have contributed to many revolutionary developments, ranging from energy production and storage, agricultural and environmental applications, and up to targeted drug delivery systems [2-8].

Unfortunately, extended manufacturing and use generally cause a significant amount of ENMs to be released into the environment (air, water, landfills and soil) [1,9]. ENM properties are most often different from those of bulk materials, sometimes posing environmental and health risks. In time, ENMs accumulate, especially in soils, and may become hazardous to soil bacteria and edible plants [10]. Plant biomass accounts for approximately $80 \%$ of the total biomass on Earth [11]. Therefore, plants can have a crucial role in the circulation of ENMs in ecosystems, their biotransformation, and bioaccumulation in the food chain [12]. ENMs can be potentially taken up from the soil by plants via their roots, and transported to their shoots, leaves and seeds, depending upon ENM size, shape, surface characteristics and charge $[13,14]$. 
Soybean (Glycine max), one of the most commercially-important crop plants in terms of seed protein and oil contents, has proven to be a perfect model for ENM accumulation studies due to its high biomass production and ease of cultivation. Moreover, the sequencing of its full genome has opened new possibilities in terms of the crop improvements needed for human and animal food production [15]. In this context, it is important in addition to evaluate the abiotic factors which may interact with the growth and yield of this crop. In the past two decades, due to important advancements in analytical and imaging techniques, numerous studies have aimed to clarify and quantify the interactions between ENMs and edible plants. However, the full toxicological profile of ENMs is far from being completely evaluated.

In this review, we aim to put into a general context (plant interactions with ENMs) the most recent research data evaluating the impact of ENMs on soybean plants, in terms of positive and negative effects on growth, production, metabolism and interaction with the plant-associated microbiota. In terms of ENMs, we aim to summarize recent studies investigating both inorganic (metal and metal-oxide nanoparticles (NPs)), and organic (carbon-based) ENMs. Finding the optimal conditions where ENM exposure is non-toxic, or even beneficial to plants, can play an important role in a future sustainable quality food production.

\section{Engineered Nanomaterials and the Environment}

There is no generally agreed definition of nanomaterials (NMs). The European Union (EU) adopted a definition of a NM through the directive 2011/696/EU, by which a NM is "a natural, incidental or manufactured material containing particles, in an unbound state or as an aggregate or as an agglomerate and where, for $50 \%$ or more of the particles in the number size distribution, one or more external dimensions is in the size range of $1 \mathrm{~nm}$ to $100 \mathrm{~nm}$." Thus, nanofilms (one nm dimension), nanowires, and nanotubes (two nm dimensions), as well as nanoparticles (NPs) (three nm dimensions) fall within the NM definition.

As very relevantly and comprehensively summarized in a relatively recent review [1], there are three main types of NMs: (i) Natural—found in the bodies of living organisms; (ii) incidental—usually, byproducts of natural and industrial phenomena; and (iii) engineered (ENMs) — produced by humans, with desired properties for certain applications. Most ENMs are less than a century old, and represent a very small fraction compared to the natural and incidental NMs [1]. ENMs can be classified into organic NMs (carbon nanotubes, graphenes and fullerenes), inorganic NMs (metals and metal oxides), organometallic NMs (modified metallic surfaces and polymer-nanoclay composites), and semiconductor nanocrystals (quantum dots) in the size range 1-100 nm, with chemical, physical and electrical properties that change as a function of the size and shape of the material and the surface functionalization [1,16]. The most abundant ENMs are metal and metal oxides (e.g., $\mathrm{TiO}_{2}, \mathrm{SiO}_{2}, \mathrm{Fe}$, $\mathrm{ZnO}, \mathrm{Al}_{2} \mathrm{O}_{3}, \mathrm{CeO}_{2}, \mathrm{Cu}$, and $\mathrm{Ag}$ ), carbon nanotubes and graphenes, and nanoclay composites [9].

The unique general properties of NMs (particle size, shape, charge, surface area and reactivity) compared to their bulk or dissolved counterparts, promoted the production of key products containing NMs in the energy [17] and electronics [4], agriculture [7,18] and water treatment [8], personal care and biomedical sectors $[2,3,5]$. In 2014, there were about 1,814 ENM-based consumer products (coatings, paints and pigments, catalytic additives and cosmetics) commercially available in 32 countries [19]; this number has increased continuously, and currently there are over 3,000 products, according to http://nanodb.dk/. From these products, ENMs are sometimes released in the environment, usually via wastewater; or deposited onto landfills after disposal $[9,20,21]$. The estimated annual quantity of ENMs released in landfills, water, soil and air was estimated to be 0.3 million metric tons in 2013 [9].

Considering the aforementioned facts, the effects of NMs on aquatic and terrestrial systems have received increasing attention in the past decades [16,20-29]. NMs of well-defined sizes were shown to actively influence the molecular processes essential for regulating cell functions [30]. Inert NMs can interact with biota via physical pathways such as biological surface coatings [31,32]. 
Owing to the high proportion of surface versus bulk atoms, even the smallest variations in surface structures may control the fate and reactivity of NMs in air, water, soil, or biota. The tendency for aggregation controlled by the surface charge, size and shape, can reveal new characteristics compared to individual NMs, and can be another important factor to consider in the impact upon the environment [1]. The continuous evolution of analytical techniques has made it possible to put into context the immediate and long-term impact of ENMs on environmental and human health at the local, regional and global levels $[9,20,33]$.

Biological systems have been continuously exposed to and affected by natural NMs [1]. However, in the past century, this exposure increased due to anthropogenic sources (incidental and engineered materials) [34]. The possible mechanisms by which NMs could affect humans were already very well summarized more than 10 years ago [34], and the authors underlined the importance of appropriate risk assessments using a multidisciplinary approach. The hazardous effects of ENMs present in consumer products are under continuous evaluation. However, their continuous evolution in terms of getting combined with other ENMs, getting coated with organic/inorganic layers to enhance their properties or improve their biocompatibility, may pose new health challenges in the future, and regulatory policies will need to keep up with this fast-developing field [35].

\section{Plant Exposure to ENMs and Toxicity Mechanisms}

Since plants are the dominant kingdom on Earth [11], they have the highest probability to be exposed to different ENMs reaching the environment. The three major sources of terrestrial plant exposure to nanomaterials are the air, water and soil, with the highest amounts of environmental accumulation in landfills and soils $[9,20,26,36,37]$. Wastewater effluents are a key aspect here, since wastewater sludge is often used as agricultural fertilizer, ending up being spread onto cultivated agricultural fields $[1,38,39]$. From the soil, NPs are taken up in the plant roots and can bioaccumulate in the plant cells and tissues $[10,12,13,16,26,27,34,40,41]$. Soil properties $(\mathrm{pH}$, ionic strength, organic matter, composition) can influence the interaction between terrestrial plants and ENMs [42]. Additionally, root-associated microorganisms play an important role in the dissolution and transformation of ENMs, which further influences the uptake of ENMs by plant cells $[13,43]$. A schematic representation of the uptake and effects of ENMs on soybean plants is given in Figure 1.

From plants, ENMs can enter the food chain via trophic transfer [44], or they can affect the second generation of plants [45] or other living organisms [33,46]. Most importantly, through the food chain, ENMs can also reach the human body, making it imperative to develop a deep understanding of their interactions with the living organisms, their potential accumulation/biomagnification and toxicity mechanisms [25,28,29,35,46-51].

Despite many publications in the field, the underlying mechanisms of NM toxicity have still not yet been fully understood, most likely since there are so many different experimental parameters even regarding the use of a single type of NM. The toxicity of a specific ENM depends on a series of factors such as: NM type, concentration and exposure time, degree of aggregation, size and shape, surface-to-volume ratio, surface functionalization, and crystal structure [30,52,53]. Regarding ENMs interaction with plants, both harmful and beneficial effects on physiological, biochemical and genetic levels have been reported in the past two decades [10,12-14,36,43,54-63].

The mechanisms more likely to influence the toxicity of ENMs in plants are: Internalization and accumulation with overproduction of reactive oxygen species (ROS), release of toxic ions, and biophysicochemical interactions (ENMs may interact dynamically with the biomolecules they meet, leading to the formation of protein coronas, particle wrapping, intracellular uptake and biocatalytic processes; in turn, the biomolecules may induce charge transfer reactions, increasing the dissolution at the NP surface). These interactions are mainly governed by properties of the NPs (size, shape, surface charge and coatings) $[29,64]$. 


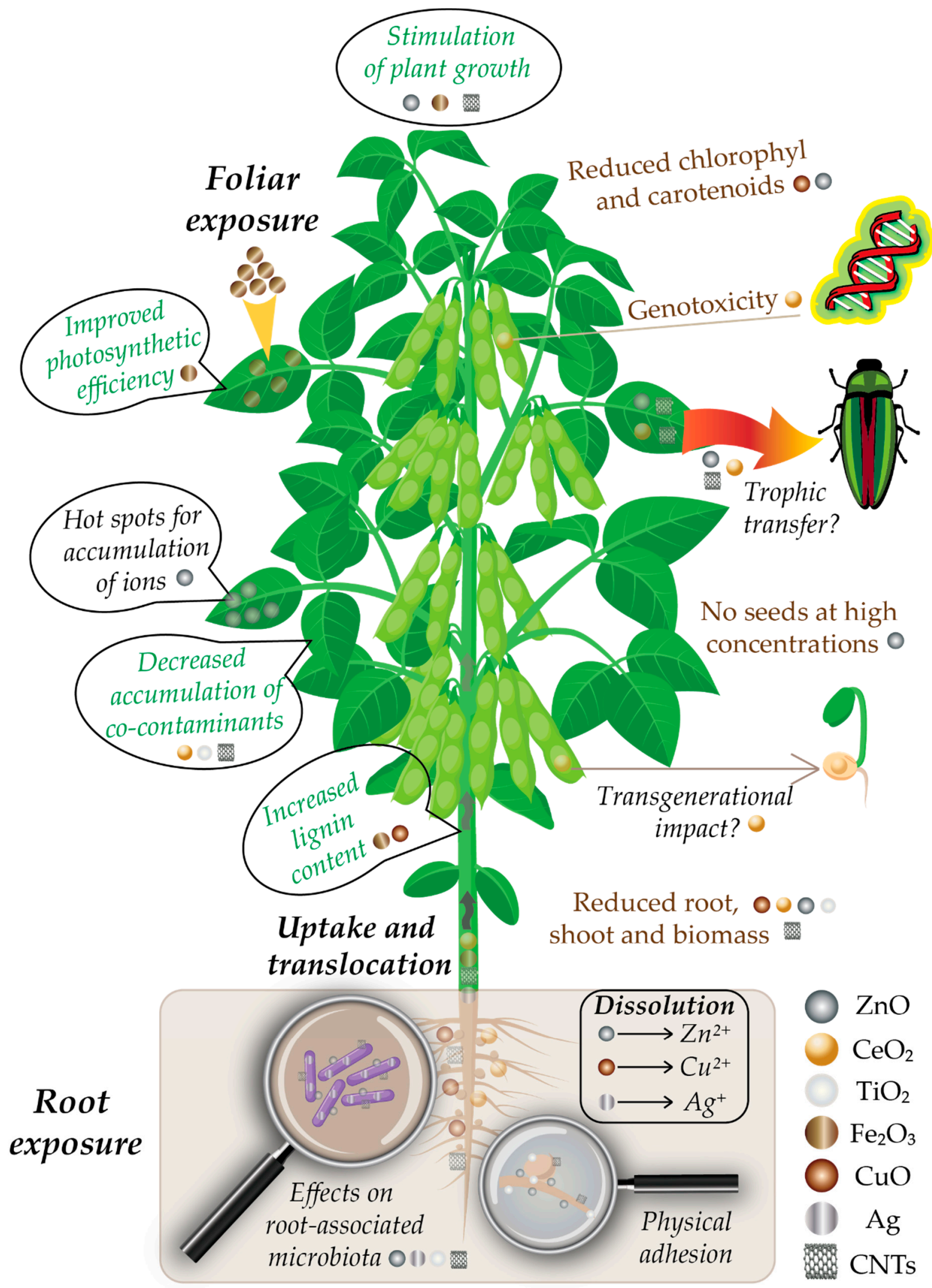

Figure 1. Schematic representation of engineered nanomaterials (ENMs) effects on soybean plants. Positive effects are depicted in green, negative ones in brown, and future research needs are followed by question marks. 
An important mechanism of nanotoxicity is the overproduction of ROS [65-67], which results in oxidative stress, lipid peroxidation, protein and DNA damage in plants $[21,23,60]$. In normal growth conditions, plants actively produce ROS in chloroplasts, mitochondria and peroxisomes, predominantly as signaling molecules for abiotic stress responses and pathogenic defense, among others [65]; and then counterbalance this oxidative stress by deploying their effective ROS scavenging antioxidant machinery (enzymatic and nonenzymatic) [66,67]. The presence of foreign ENMs can however overstimulate ROS production $[21,23,60]$, with negative effects on plant growth and metabolism [57,68].

Oxidative stress is a common mechanism of phytotoxicity documented over a wide range of reactive ENMs with variable physicochemical properties (size, composition, surface chemistry (defects, charge), energy band gap and ionic dissolution levels) [57,69].

Therefore, the presence of ENMs inside cells can impact the cellular redox balance, leading to an overproduction of ROS, depending on their physicochemical properties [69]. For metal oxide NPs, the most frequently-detected indicators of ROS-induced phytotoxicity are the increased production of $\mathrm{H}_{2} \mathrm{O}_{2}$ and malondialdehyde, and altered activities of enzymes such as catalase, superoxide dismutase and ascorbate peroxidase [57].

The level of oxidative stress is concentration-dependent: High-dose ENMs exposure does result in ROS overproduction and therefore cytotoxicity; low-dose exposure (e.g., $\mathrm{ZnO}<50 \mathrm{mg} / \mathrm{kg}$ of soil) may lead to non-toxic modulation of redox signaling, which may influence disease initiation and progression $[69,70]$. Oxidative stress can also be a consequence of the ENM-mediated redox state modulation of thiol sulfur switches, which normally function in cell signaling and physiological regulation $[71,72]$.

Some metal and metal-based NPs can dissolve in biologic environments [38], therefore releasing metallic ions which can be up-taken by the plants at greater rates and have higher reactivities than their NP parent. Ag NPs are a very good example, with numerous studies assessing their environmental (bio)transformation and biological effects on plants [73]. Dissolution of Ag NPs is more likely to occur for the smaller particle size (decreased surface area) [74]. $\mathrm{ZnO}$ and $\mathrm{CuO}$ are other very good examples which cause serious oxidative damage through ionic dissolution $[75,76]$. For $\mathrm{ZnO}$, toxicity was shown to be a combination of ROS overproduction, NP and ionic toxicity [77-79], although ionic toxicity was shown to be more pronounced than the others [79].

For inert NPs (those not releasing toxic metal ions, e.g., organic NMs) during the aquatic life cycle, adsorption at biological surfaces is proposed as a toxicity-related mechanism [10,80]. These effects are evidently mostly size- and charge-dependent $[30,53]$. Some metal oxides NPs are also known to be relatively inert in biological media (e.g., $\mathrm{TiO}_{2}, \mathrm{Fe}_{3} \mathrm{O}_{4}$ ) [81,82], and the formation of a biomolecule corona around them can have a tremendous effect upon their subsequent behavior, including uptake rates $[31,83]$. In this case, the medium $\mathrm{pH}$, inorganic matter and the occurrence and diversity of the natural organic matter in the soil can have both stabilizing and destabilizing effects on the ENMs [83]. Accumulation of $\mathrm{TiO}_{2}$ was shown to have detrimental effects by reducing the hydraulic conductivity of the cell wall of maize seedlings, leading to reduced transpiration and leaf growth [84]. $\mathrm{Fe}_{3} \mathrm{O}_{4} \mathrm{NPs}$ adsorbed on the root surface of pumpkin plants were thought to cause local instability of the cell wall [85].

\section{Soybean Interactions with ENMs}

Soya bean has proven to be a perfect model for metal accumulation studies due to high biomass production and ease of cultivation. Numerous data have been published in the past decade about the effect of various ENMs on soybean (Table 1), mainly focusing on $\mathrm{ZnO}$ [86-94], $\mathrm{CeO}_{2}$ [86-92,95-102], $\mathrm{TiO}_{2}$ [95,103-105], $\mathrm{Fe}_{2} \mathrm{O}_{3}$ [106-110], $\mathrm{Fe}_{3} \mathrm{O}_{4}$ [104], $\mathrm{CuO}$ [111], $\mathrm{Cr}_{2} \mathrm{O}_{3}$ [112], $\mathrm{Ag}$ [113-116] and carbon-based materials [117-123], and the results are summarized in the following sections. 
Table 1. Soybean interaction with various ENMs.

\begin{tabular}{|c|c|c|c|c|c|}
\hline NM & Form; Size & Conc. & $\begin{array}{l}\text { Growth } \\
\text { Conditions }\end{array}$ & Effects & Ref. \\
\hline \multirow{9}{*}{$\mathrm{ZnO}$} & $\begin{array}{l}\text { NPs hexagonal; } \\
8 \mathrm{~nm}\end{array}$ & $0-4 \mathrm{~g} / \mathrm{L}$ & $\begin{array}{l}\text { Germination } \\
\text { tests }\end{array}$ & $\begin{array}{l}\mathrm{ZnO} \text { NPs dissolved as } \mathrm{Zn}^{2+} \text { had no } \\
\text { effect on germination. }\end{array}$ & [86] \\
\hline & $\begin{array}{l}\text { NPs powder in } \\
\text { soil; } 10 \mathrm{~nm}\end{array}$ & $0.5-5 \mathrm{~g} / \mathrm{kg}$ soil & $\begin{array}{l}\text { Garden pots } \\
\text { with } 2.4 \mathrm{~kg} \text { of } \\
\text { soil }\end{array}$ & $\begin{array}{l}\text { Zn bioaccumulated in all tissues } \\
\text { and especially in the leaves. } \mathrm{ZnO} \\
\text { slightly stimulated plant growth. }\end{array}$ & [87] \\
\hline & $\begin{array}{l}\text { NPs powder in } \\
\text { soil; } \sim 10 \mathrm{~nm}\end{array}$ & $0.5 \mathrm{~g} / \mathrm{kg}$ soil & Same as in [87] & $\begin{array}{l}\text { ZnO NPS were dissolved and } \\
\text { accumulated in the seeds in a form } \\
\text { resembling Zn citrate. }\end{array}$ & [88] \\
\hline & $\begin{array}{l}\text { NPs powder in } \\
\text { soil; 10 nm }\end{array}$ & $0-0.5 \mathrm{~g} / \mathrm{kg}$ soil & Same as in [87] & $\begin{array}{l}\mathrm{ZnO} \text { impacted the accumulation of } \\
\text { essential elements }(\mathrm{K}, \mathrm{Mg}) . \mathrm{Zn} \\
\text { accumulation was significantly } \\
\text { increased in all plant organs. }\end{array}$ & [89] \\
\hline & $\begin{array}{l}\text { NPs powder in } \\
\text { soil; } 10 \mathrm{~nm}\end{array}$ & $0-0.5 \mathrm{~g} / \mathrm{kg}$ soil & Same as in [87] & $\begin{array}{l}\text { ZnO significantly altered soil } \\
\text { microbiota both in unplanted and } \\
\text { planted soils; the presence of plants } \\
\text { reduced effects on soil bacteria. }\end{array}$ & [90] \\
\hline & $\begin{array}{l}\text { NPs powder in } \\
\text { soil; } 10 \mathrm{~nm}\end{array}$ & 0-0.5 g/kg soil & Same as in [87] & $\begin{array}{l}\text { ZnO NPs decreased chlorophyll } \\
\text { concentrations and had some } \\
\text { genotoxic effects at the highest } \\
\text { concentration }(0.5 \mathrm{~g} / \mathrm{kg} \text { soil). }\end{array}$ & [91] \\
\hline & $\mathrm{NPs} ;<50 \mathrm{~nm}$ & $0-0.5 \mathrm{~g} / \mathrm{kg}$ soil & Soil (65 d) & $\begin{array}{c}\text { ZnO NPs reduced roots and shoots } \\
\text { (area and volume). Plants treated } \\
\text { with high conc. }(0.5 \mathrm{~g} / \mathrm{kg} \text { ) had no } \\
\text { seeds. }\end{array}$ & [92] \\
\hline & NPs; $40-60 \mathrm{~nm}$ & $0.025-0.5 \mathrm{~g} / \mathrm{L}$ & $\begin{array}{l}\text { Germination } \\
\text { tests }\end{array}$ & $\begin{array}{l}\mathrm{ZnO} \text { promoted the growth of } \\
\text { primary roots and supported the } \\
\text { development of first trifoliate leaves } \\
\text { earlier than the control. }\end{array}$ & [93] \\
\hline & NPs; $41 \mathrm{~nm}$ & 0-400 ppm & $\begin{array}{l}\text { Hoagland } \\
\text { medium }(21 \mathrm{~d})\end{array}$ & $\begin{array}{l}\text { ZnO NPs reduced chlorophyll and } \\
\text { carotenoids, and increased } \\
\text { anthocyanin, malondialdehyde, } \\
\mathrm{H}_{2} \mathrm{O}_{2} \text { and phenylalanine } \\
\text { ammonia-lyase activity. }\end{array}$ & [94] \\
\hline \multirow{5}{*}{$\mathrm{CeO}_{2}$} & $\begin{array}{l}\text { NPs cubic; } 7 \\
\text { nm }\end{array}$ & $0-4 \mathrm{~g} / \mathrm{L}$ & $\begin{array}{l}\text { Germination } \\
\text { tests }\end{array}$ & $\begin{array}{l}\mathrm{CeO}_{2} \mathrm{NPs} \text { remained intact in roots } \\
\text { and had genotoxic effects. }\end{array}$ & [86] \\
\hline & $\begin{array}{l}\text { NPs powder in } \\
\text { soil; } \sim 8 \mathrm{~nm}\end{array}$ & $1-10 \mathrm{~g} / \mathrm{kg}$ soil & $\begin{array}{l}\text { Garden pots } \\
\text { with } 2.4 \mathrm{~kg} \text { of } \\
\text { soil }\end{array}$ & $\begin{array}{l}\mathrm{CeO}_{2} \mathrm{NPs} \text { decreased plant growth } \\
\text { and yield, stopped nitrogen fixation } \\
\text { at high conc.; no effect on seed } \\
\text { production. }\end{array}$ & [87] \\
\hline & $\begin{array}{l}\text { NPs powder in } \\
\text { soil; } \sim 8 \mathrm{~nm}\end{array}$ & $1 \mathrm{~g} / \mathrm{kg}$ soil & Same as in [87] & $\begin{array}{l}\mathrm{CeO}_{2} \mathrm{NPs} \text { were in the root nodule } \\
\text { including root epidermis and pods. } \\
\text { NPs were also shown to potentially } \\
\text { transfer to next plant generation via } \\
\text { the reproductive organs. }\end{array}$ & [88] \\
\hline & $\begin{array}{l}\text { NPs powder in } \\
\text { soil; } \sim 8 \mathrm{~nm}\end{array}$ & $0-1 \mathrm{~g} / \mathrm{kg}$ soil & Same as in [87] & $\begin{array}{l}\mathrm{CeO}_{2} \text { interfered with the uptake of } \\
\text { elements involved in nitrogen } \\
\text { metabolism and photosynthesis (Ca, } \\
\qquad \mathrm{Mg}, \mathrm{P}, \mathrm{K} \text {, and } \mathrm{S}) \text {. }\end{array}$ & [89] \\
\hline & $\begin{array}{l}\text { NPs powder in } \\
\text { soil; } \sim 8 \mathrm{~nm}\end{array}$ & $0-1 \mathrm{~g} / \mathrm{kg}$ soil & Same as in [87] & $\begin{array}{l}\mathrm{CeO}_{2} \text { had no effect in unplanted } \\
\text { soils; the presence of plants } \\
\text { promoted the altering of bacterial } \\
\text { communities in planted soils. }\end{array}$ & [90] \\
\hline
\end{tabular}


Table 1. Cont.

\begin{tabular}{|c|c|c|c|c|c|}
\hline NM & Form; Size & Conc. & $\begin{array}{l}\text { Growth } \\
\text { Conditions }\end{array}$ & Effects & Ref. \\
\hline & $\begin{array}{l}\text { NPs powder in } \\
\text { soil; } \sim 8 \mathrm{~nm}\end{array}$ & 0-1 g/kg soil & Same as in [87] & $\begin{array}{c}\mathrm{CeO}_{2} \mathrm{NPs} \text { caused signs of oxidative } \\
\text { damage in leaves with } \\
\text { consequences to the entire plant. }\end{array}$ & [91] \\
\hline & NPs; 25 nm & 0-1 g/kg soil & $\begin{array}{l}\text { Germination } \\
\text { tests }\end{array}$ & $\begin{array}{l}\mathrm{CeO}_{2} \mathrm{NPs} \text { did not significantly } \\
\text { affect germination and root. }\end{array}$ & [95] \\
\hline & NPs; 30-50 nm & $7 \mathrm{mg} / \mathrm{L}$ & $\begin{array}{l}\text { Hydroponic } \\
\text { growth }\end{array}$ & $\begin{array}{l}\text { Dissolved Ce was found for the first } \\
\text { time in plant seedling shoots } \\
\text { exposed to NPs hydroponically. }\end{array}$ & [96] \\
\hline & NPs; 10-30 nm & $0-0.5 \mathrm{~g} / \mathrm{kg}$ soil & $\begin{array}{l}\text { Greenhouse (3 } \\
\text { wk) }\end{array}$ & $\begin{array}{l}\text { At } 0.1 \mathrm{~g} / \mathrm{kg}, \mathrm{CeO}_{2} \mathrm{NPs} \text { stimulated } \\
\text { plant growth and photosynthesis } \\
(+54 \%) . \text { Photosynthesis rate } \\
\text { decreased at } 0.5 \mathrm{~g} / \mathrm{kg}(\sim 36 \%) .\end{array}$ & [97] \\
\hline & NPs; 10-30 nm & $0.1 \mathrm{~g} / \mathrm{kg}$ soil & $\begin{array}{l}\text { Greenhouse (3 } \\
\text { wk) }\end{array}$ & $\begin{array}{l}\mathrm{CeO}_{2} \mathrm{NPs} \text { was dependent on soil } \\
\text { moisture, with positive effects } \\
\text { (increased fresh biomass) above } 70 \% \\
\text { moisture content. }\end{array}$ & [98] \\
\hline & $\mathrm{NPs} ; \sim 42 \mathrm{~nm}$ & 0-0.5 g/kg soil & $\begin{array}{l}\text { Greenhouse (30 } \\
\text { d) }\end{array}$ & $\begin{array}{l}\mathrm{CeO}_{2} \mathrm{NPs} \text { enhanced the plant light } \\
\text { energy use efficiency by } \\
\text { photosystem II. The presence of } \mathrm{Cd} \\
\text { significantly increased Ce } \\
\text { accumulation in plant tissues. }\end{array}$ & [99] \\
\hline & $\mathrm{NPs} ; ~ 42 \mathrm{~nm}$ & $0.1 \mathrm{~g} / \mathrm{L}(+\mathrm{Cd})$ & $\begin{array}{l}\text { Hydroponic } \\
\text { growth }\end{array}$ & $\begin{array}{c}\mathrm{CeO}_{2} \mathrm{NPs} \text { and } \mathrm{Cd} \text { interacted } \\
\text { significantly, affecting their } \\
\text { accumulation: } \mathrm{CeO}_{2} \text { reduced the } \\
\text { translocation of } \mathrm{Cd} \text { from roots to } \\
\text { shoots by } 70 \% \text {; Cd lowered the conc. } \\
\text { of } \mathrm{Ce} \text { in roots by } 45 \% \text { but increased } \\
\text { it in shoots by } 60 \% \text {. }\end{array}$ & [100] \\
\hline & NPs; $20-200 \mathrm{~nm}$ & $0-2 \mathrm{~g} / \mathrm{kg}$ soil & Greenhouse & $\begin{array}{c}\text { Root biomass was reduced by } 60 \% \\
\text { and by } 81 \% \text {, while shoot biomass } \\
\text { increased by } 65 \% \text { and } 92 \% \text { at } 0.5 \\
\text { and } 2 \mathrm{~g} / \mathrm{kg} \mathrm{CeO} .\end{array}$ & [101] \\
\hline & NPs; 10 nm & $0-0.5 \mathrm{~g} / \mathrm{kg}$ soil & $\begin{array}{l}\text { Greenhouse (27 } \\
\text { d) }\end{array}$ & $\begin{array}{l}\text { Initial soil sterilization affected } \\
\text { interaction of } \mathrm{CeO}_{2} \mathrm{NPs} \text { with plants } \\
\text { and } \mathrm{CeO}_{2} \text { accumulation. The net } \\
\text { photosynthesis rate was higher at } \\
0.1 \mathrm{~g} / \mathrm{kg} \text { but lower at } 0.5 \mathrm{~g} / \mathrm{kg} \text {, as } \\
\text { compared to the unsterilized soil. }\end{array}$ & [102] \\
\hline \multirow{4}{*}{$\mathrm{TiO}_{2}$} & NPs; 25 nm & $0-1 \mathrm{~g} / \mathrm{kg}$ soil & $\begin{array}{l}\text { Germination } \\
\text { tests }\end{array}$ & $\begin{array}{c}\mathrm{TiO}_{2} \text { NPs showed a marginal effect } \\
\text { on germination. }\end{array}$ & [95] \\
\hline & NPs; $<60 \mathrm{~nm}$. & $<0.2 \mathrm{~g} / \mathrm{kg}$ soil & $\begin{array}{l}\text { Greenhouse }(6 \\
\text { wk) }\end{array}$ & $\begin{array}{l}\mathrm{TiO}_{2} \text { was found in roots; no effects } \\
\text { on plant growth, nutrient content, } \\
\text { or the composition of } \\
\text { root-associated microbiota. }\end{array}$ & [103] \\
\hline & NPs; $22-25 \mathrm{~nm}$ & $0-0.2 \mathrm{~g} / \mathrm{kg}$ soil & $\begin{array}{l}\text { Greenhouse }(6 \\
\text { wk) }\end{array}$ & $\begin{array}{c}\mathrm{TiO}_{2} \text { significantly reduced plant } \\
\text { growth. }\end{array}$ & [104] \\
\hline & $\mathrm{NPs} ;<100 \mathrm{~nm}$ & $\begin{array}{l}0.1-0.3 \mathrm{~g} / \mathrm{kg} \text { soil } \\
\quad(+\mathrm{Cd})\end{array}$ & $\begin{array}{l}\text { Plant growth } \\
\text { chamber }\end{array}$ & $\begin{array}{l}\mathrm{TiO}_{2} \mathrm{NPs} \text { restricted Cd-induce } \\
\text { toxicity by increasing the } \\
\text { photosynthetic rate and growth } \\
\text { parameters of the plants. }\end{array}$ & [105] \\
\hline
\end{tabular}


Table 1. Cont

\begin{tabular}{|c|c|c|c|c|c|}
\hline NM & Form; Size & Conc. & $\begin{array}{l}\text { Growth } \\
\text { Conditions }\end{array}$ & Effects & Ref. \\
\hline \multirow{5}{*}{$\mathrm{Fe}_{2} \mathrm{O}_{3}$} & \multirow{2}{*}{$\begin{array}{c}\text { Sprayed } \\
\text { nano- } \mathrm{Fe}_{2} \mathrm{O}_{3}\end{array}$} & \multirow[t]{2}{*}{$0.25-1 \mathrm{~g} / \mathrm{L}$} & \multirow{2}{*}{$\begin{array}{l}\text { Clay soil }(\mathrm{pH} \\
7.6)\end{array}$} & $\begin{array}{c}\mathrm{Fe}_{2} \mathrm{O}_{3} \mathrm{NPs} \text { enhanced pod and grain } \\
\text { biomass by } 48 \% .\end{array}$ & [106] \\
\hline & & & & $\begin{array}{l}\mathrm{Fe}_{2} \mathrm{O}_{3} \mathrm{NPs} \text { at } 0.75 \mathrm{~g} / \mathrm{L} \text { enhanced } \\
\text { protein }(33.8 \%) \text { and lipid }(25.4 \%) \\
\text { content } v \text { s control; increased fatty } \\
\text { acids, minerals and chlorophyll. }\end{array}$ & [107] \\
\hline & $\begin{array}{l}\text { NPs; } 6 \mathrm{~nm} . \\
\text { Foliar } v s \text { soil } \\
\text { treatment. }\end{array}$ & $0.05-2 \mathrm{~g} / \mathrm{L}$ & Wagner pots & $\begin{array}{l}\mathrm{Fe}_{2} \mathrm{O}_{3} \mathrm{NPs} \text { produced positive } \\
\text { effects on root elongation, shoot } \\
\text { weight, leaf area, and soil plant } \\
\text { analysis development values. }\end{array}$ & [108] \\
\hline & $\begin{array}{l}\text { Superparamagnetic } \\
\text { NPs; } 9 \mathrm{~nm} \text {. }\end{array}$ & $0.2-2 \mathrm{~g} / \mathrm{L}$ & $\begin{array}{l}\text { Hydroponic } \\
\text { growth }\end{array}$ & $\begin{array}{l}\text { NPs significantly enhanced the } \\
\text { chlorophyll content in subapical } \\
\text { leaves, with no trace of toxicity. }\end{array}$ & [109] \\
\hline & NPs; $<50 \mathrm{~nm}$ & $0.2-1.5 \mathrm{~g} / \mathrm{L}$ & $\begin{array}{l}\text { Hoagland } \\
\text { nutrient } \\
\text { solution }\end{array}$ & $\begin{array}{l}\mathrm{Fe}_{2} \mathrm{O}_{3} \mathrm{NPs} \text { increased the lignin } \\
\text { content of roots and stems, followed } \\
\text { by the stiffening of the cell wall and } \\
\text { growth inhibition. }\end{array}$ & [110] \\
\hline $\mathrm{Fe}_{3} \mathrm{O}_{4}$ & NPs; 18 nm & $0-0.2 \mathrm{~g} / \mathrm{kg}$ soil & $\begin{array}{l}\text { Greenhouse (6 } \\
\text { wk). }\end{array}$ & $\begin{array}{c}\mathrm{Fe}_{3} \mathrm{O}_{4} \mathrm{NPs} \text { increased plant growth } \\
\text { and leaf } \mathrm{C} \text { but reduced } \mathrm{P} \text { content. } \\
\text { Negatively charged } \mathrm{Fe}_{3} \mathrm{O}_{4} \mathrm{NPs} \\
\text { increased leaf } \mathrm{P} \text { content, and } \\
\text { decreased root colonization of } \\
\text { rhizobia, vs positive NPs. }\end{array}$ & [104] \\
\hline $\mathrm{CuO}$ & NPs; $50 \mathrm{~nm}$ & $0-0.5 \mathrm{~g} / \mathrm{L}$ & $\begin{array}{l}\text { Murashige and } \\
\text { Skoog medium }\end{array}$ & $\begin{array}{l}\text { CuO NPs increased lignification of } \\
\text { root cells via improving root } \\
\text { peroxidases activity; and reduced } \\
\text { the shoot growth, weight, and total } \\
\text { chlorophyll content. }\end{array}$ & [111] \\
\hline $\mathrm{Cr}_{2} \mathrm{O}_{3}$ & NPs; $50 \mathrm{~nm}$ & $0.01-0.5 \mathrm{~g} / \mathrm{L}$ & $\begin{array}{l}\text { Suspensions } \\
\text { with NPs }\end{array}$ & $\begin{array}{l}\mathrm{Cr}_{2} \mathrm{O}_{3} \mathrm{NPs} \text { inhibited plant growth } \\
\text { by damaging photosynthesis, } \\
\text { destroying the chloroplast thylakoid } \\
\text { structure and inhibiting electron } \\
\text { acceptors. }\end{array}$ & [112] \\
\hline \multirow{4}{*}{$\mathrm{Ag}$} & $\begin{array}{l}\text { NPs or bulk; } \\
68-91 \mathrm{~nm} \text {. }\end{array}$ & $0.5-2 \mathrm{~g} / \mathrm{L}$ & $\begin{array}{l}125 \mathrm{~mL} \text { jars of } \\
\text { vermiculite }\end{array}$ & $\begin{array}{l}\text { Ag NP-exposed plants had } 1.9-2.2 \mathrm{x} \\
\text { higher Ag content and transport to } \\
\text { shoot tissues. Ag altered DDE (a } \\
\text { co-contaminant) accumulation and } \\
\text { translocation. }\end{array}$ & [113] \\
\hline & NPs; $2-80 \mathrm{~nm}$ & $0.2-20 \mathrm{ppm}$ & $\begin{array}{c}\text { Soybean } \\
\text { exposed to } \\
\text { flooding stress }\end{array}$ & $\begin{array}{l}\text { Ag NPs positively influenced the } \\
\text { growth performance of soybeans } \\
\text { under flooding stress. }\end{array}$ & [114] \\
\hline & $\mathrm{NPs} ; \sim 60 \mathrm{~nm}$ & $\begin{array}{l}0.15-0.31^{*} 10^{12} \\
\mathrm{NPs} / \mathrm{mL}\end{array}$ & $\begin{array}{l}\text { Standard } \\
\text { germination } \\
\text { tests }\end{array}$ & $\begin{array}{c}\text { Ag NPs did not present any } \\
\text { negative effects on the germination } \\
\text { and growth. }\end{array}$ & [115] \\
\hline & $\mathrm{NPs} ; \sim 60 \mathrm{~nm}$ & $\begin{array}{c}50 \mathrm{mg} / \mathrm{kg} \text { vs } \\
\mathrm{AgNO}_{3}\end{array}$ & $\begin{array}{l}\text { Greenhouse ( } 21 \\
\text { d). }\end{array}$ & $\begin{array}{l}\text { Ag NPs decreased the mass } \\
\text { production of non-transgenic plants } \\
\text { by } 25 \% \text { by generating oxidative } \\
\text { stress. }\end{array}$ & [116] \\
\hline
\end{tabular}


Table 1. Cont.

\begin{tabular}{|c|c|c|c|c|c|}
\hline NM & Form; Size & Conc. & $\begin{array}{l}\text { Growth } \\
\text { Conditions }\end{array}$ & Effects & Ref. \\
\hline \multirow{8}{*}{ C } & $\begin{array}{l}\text { MWCNTs, od } \\
13 \mathrm{~nm}, \mathrm{id} \sim 4 \\
\mathrm{~nm}, 1>1 \mu \mathrm{m}\end{array}$ & $0-2 \mathrm{~g} / \mathrm{L}$ & $\begin{array}{l}\text { Hydroponics } \\
\quad(15 \mathrm{~d})\end{array}$ & $\begin{array}{l}\text { MWCNTs induced very little or no } \\
\text { effect on root and shoot growth, cell } \\
\text { death, and electrolyte leakage at the } \\
\text { seedling stage. }\end{array}$ & [117] \\
\hline & \multirow[t]{2}{*}{$\begin{array}{l}\text { MWCNTs, od } \\
15-40 \mathrm{~nm} ; 1 \text { - } \\
\text { several } \mu \mathrm{m}\end{array}$} & $0-200 \mu \mathrm{g} / \mathrm{mL}$ & Agar medium & $\begin{array}{l}\text { MWCNTs accelerated seed } \\
\text { germination, increased roots, and } \\
\text { showed no negative effects on plant } \\
\text { development. }\end{array}$ & [118] \\
\hline & & $50 \mu \mathrm{g} / \mathrm{mL}$ & $\begin{array}{l}\text { Hydroponics } \\
\text { (20 wk) }\end{array}$ & $\begin{array}{l}\text { MWCNTs decreased the roots } \\
\text { weight; no influence on shoot } \\
\text { reduction or the development of } \\
\text { other organs was observed; CNTs } \\
\text { enhanced photosynthesis. }\end{array}$ & [119] \\
\hline & $\begin{array}{c}\text { MWCNTs; od } \\
20-70 \mathrm{~nm} \text {, id } \\
5-10 \mathrm{~nm}, 1>2 \\
\mu \mathrm{m}\end{array}$ & $1 \mathrm{~g} / \mathrm{L}$ & $\begin{array}{l}\text { Suspensions } \\
\text { with CNTs }(36 \\
\text { h) }\end{array}$ & $\begin{array}{l}\text { MWCNTs treatment reduced the } \\
\text { total root length by } 29 \% \text {, induced } \\
\text { oxidative stress. }\end{array}$ & [120] \\
\hline & $\begin{array}{l}\text { MWCNTs, d } \\
20-30 \mathrm{~nm}, 1- \\
0.05-2.0 \mu \mathrm{m}\end{array}$ & $10-50.0 \mathrm{mg} / \mathrm{L}$ & $\begin{array}{l}\text { Hydroponics } \\
(18 \mathrm{~d})\end{array}$ & $\begin{array}{l}\text { MWCNTs inhibited growth and } \\
\text { transpiration; increased dry weight } \\
\text { biomass (@20 mg/L); the effect was } \\
\text { influenced by the MWCNTs charge. }\end{array}$ & [121] \\
\hline & $\begin{array}{l}\text { MWCNTs, hd } \\
3.5-3.9 \mu \mathrm{m} \\
(0.5-1 \mathrm{~g} / \mathrm{L}) \text { and } \\
17.7 \mu \mathrm{m}(5 \mathrm{~g} / \mathrm{L})\end{array}$ & $0-5 \mathrm{~g} / \mathrm{kg}$ soil & Soil (28 d) & $\begin{array}{l}\text { MWCNTs induced phytotoxicity; } \\
\text { reduced biomass }(19.2-26.9 \%), \\
\text { reduced net growth }(29.8-31.9 \%) \text {. } \\
\text { Co-exposure with contaminants } \\
\text { decreased chlordane and DDx } \\
\text { accumulation. }\end{array}$ & [122] \\
\hline & \multirow[t]{2}{*}{$\begin{array}{c}C_{60} \text { (fullerenes), } \\
1450-1900 \mathrm{~nm}\end{array}$} & $0-5 \mathrm{~g} / \mathrm{kg}$ soil & Soil (28 d) & $\begin{array}{c}\mathrm{C}_{60} \text { induced phytotoxicity; reduced } \\
\text { biomass and net growth by } \\
25.0-40.4 \% \text { and } 27.7-42.6 \% \\
\text { Co-exposure with contaminants } \\
\text { increased chlordane uptake. }\end{array}$ & [122] \\
\hline & & $40 \mathrm{mg} / 80 \mathrm{~mL}$ & $\begin{array}{l}\text { Vermiculite (3 } \\
\text { wk) }\end{array}$ & $\begin{array}{l}\text { Fullerene treatment decreased } \\
\text { accumulation of } \mathrm{p}, \mathrm{p}^{\prime} \text {-DDE } \\
\text { contaminant in shoots }(48 \%) ; \text { root } \\
\text { and total plant } \mathrm{p}, \mathrm{p}^{\prime} \text {-DDE increased. }\end{array}$ & [123] \\
\hline
\end{tabular}

NPs - nanoparticles; d - day; wk - week; DDE - dichlorodiphenyldichloroethylene; d - diameter; 1 - length; id/od/hd

- internal/outer/hydrodynamic diameter.

\section{1. $\mathrm{ZnO}$ and $\mathrm{CeO}_{2} \mathrm{NPs}$}

The bioaccumulation and biotransformation of $\mathrm{ZnO}$ and $\mathrm{CeO}_{2} \mathrm{NPs}$ in soybean grown in hydroponic, greenhouse or NP-impacted soil conditions, have been investigated extensively over the past 10 years [86-92]. López-Moreno et al. [86] used X-ray absorption spectroscopy to show for the first time that cubical $\mathrm{CeO}_{2} \mathrm{NPs}(7 \mathrm{~nm})$ were stored in the roots of the plants grown hydroponically in the nanoform, while hexagonal $\mathrm{ZnO}$ NPs $(8 \mathrm{~nm})$ could not be determined in the roots except as the $\mathrm{Zn}$ (II) ionic form, demonstrating a material-dependent effect on soybean plants. It was already shown previously that dissolution plays an important role in $\mathrm{ZnO}$-induced plant cytotoxicity, while the antioxidant properties of $\mathrm{CeO}_{2}$ may protect cells from oxidant injury [128]. ZnO NPs were shown to dissolve in aqueous conditions to form hydrated $\mathrm{Zn}^{2+}$ cations $[10,57,124]$. Germination of seeds was not significantly affected by either of the NPs, except for $\mathrm{CeO}_{2}$ at $2 \mathrm{~g} / \mathrm{L}$, but $\mathrm{CeO}_{2}$ was shown to significantly increase root elongation at all tested concentrations $(0.5-4 \mathrm{~g} / \mathrm{L})$. ZnO-treated seedlings 
also showed an increased root length at lower concentrations, with a maximum length at $0.5 \mathrm{~g} / \mathrm{L}$; however, root length decreased compared to control at higher concentrations, and reached a minimum at $4 \mathrm{~g} / \mathrm{L}$ [86]. $\mathrm{CeO}_{2}$ was shown to exhibit genotoxic effects (DNA damage) on the soybean plants, but only at the highest concentrations tested ( 2 and $4 \mathrm{~g} / \mathrm{L})$, which strongly exceed realistic environmental concentrations, which, in the European Union (EU) for example, have been estimated to be in the ng/L range in surface water and $\mu \mathrm{g} / \mathrm{kg}$ in soils [125].

A few years later, the first study of a soybean grown to maturity in NP-impacted soil showed that plant growth (root and shoot length, number of leaves) was negatively affected even at low $\mathrm{CeO}_{2} \mathrm{NPs}$ $(8 \mathrm{~nm})$ concentrations $(0.1 \mathrm{~g} / \mathrm{kg}$ soil), but slightly stimulated by ZnO NPs $(8 \mathrm{~nm})$ at similar concentrations in the soil $(0.05-0.1 \mathrm{~g} / \mathrm{kg})$ [87]. $\mathrm{CeO}_{2}$, as assessed via energy dispersive X-ray spectroscopy (EDX) and dark-field scanning transmission electron microscopy (TEM), accumulated mainly in the roots and nodules (very little aboveground translocation) with similar rates to those from the previous hydroponic study [86].

The accumulated quantities of Ce in the roots were 400 times higher at $1 \mathrm{~g} / \mathrm{kg}$ compared to $0.1 \mathrm{~g} / \mathrm{kg}$ of soil, and this accumulation almost shut down the $\mathrm{N}_{2}$ fixation in the roots. Unlike $\mathrm{Ce}, \mathrm{Zn}$ accumulated in a dose-dependent fashion in the stem, leaf and pod tissues (visible by TEM). The concentration in the leaves, determined with ICP-OES or ICP-MS, was three times higher than that in the stem, suggesting that leaves act as "hot spots" for Zn bioaccumulation [87]. Since the bioaccumulation results were close to those from a previous study with Zn salts [126], the authors suggested that most of Zn present in plant cells may have dissolved from the NPs [87].

In a subsequent study, Hernandez-Viezcas et al. [88] showed via X-ray absorption spectroscopy that $\mathrm{CeO}_{2} \mathrm{NPs}(8 \mathrm{~nm})$ remained mainly as particles in the root and nodules, while for $\mathrm{ZnO}(10 \mathrm{~nm})$, the presence of NPs could not be confirmed; various Zn complexes (resembling Zn citrate or nitrate) were identified within the stem, leaves and beans, but none as NPs [88]. This study also showed that a fraction of $\mathrm{CeO}_{2} \mathrm{NPs}$ and $\mathrm{Zn}^{2+}$ ions reached the reproductive/edible portion of the soybean plant, suggesting that $\mathrm{CeO}_{2} \mathrm{NPs}$ can potentially reach the food chain and the next plant generation [88]. The transgenerational impact of $\mathrm{CeO}_{2} \mathrm{NPs}$ was shown on the growth and development of tomato plants, where the second generation seedlings from parents treated with $\mathrm{CeO}_{2} \mathrm{NPs}$ had smaller biomass, water transpiration and slightly higher ROS content [45].

Next, Peralta-Videa et al. [89] have shown that $\mathrm{CeO}_{2}(8 \mathrm{~nm})$ and $\mathrm{ZnO}$ NPs $(10 \mathrm{~nm})$ had different effects on the accumulation of nutrients in soybean plants grown in NP-impacted farm soil, therefore altering the nutritional value of the plants. $\mathrm{CeO}_{2}$ exposure $(0.1-1 \mathrm{~g} / \mathrm{kg})$ interfered mainly with the uptake of the chemical elements responsible for nitrogen metabolism and photosynthesis: The levels of $\mathrm{Ca}, \mathrm{Mg}, \mathrm{K}$ and $\mathrm{Na}$ decreased significantly, but $\mathrm{P}$ and $\mathrm{Cu}$ increased in pods. $\mathrm{ZnO}$ exposure $(0.05-0.5 \mathrm{~g} / \mathrm{kg})$ impacted the most the accumulation of essential elements, increasing $\mathrm{Zn}, \mathrm{Mn}$ and $\mathrm{Cu}$ in pods, and Mo in nodules, but decreasing Fe accumulation in leaves [89]. As in the previous study [88], Zn was significantly present in all analyzed soybean organs, including pods.

In a similar study, $\mathrm{Ge}$ et al. [90] investigated the effect of $\mathrm{CeO}_{2}$ (nanorods; $67 \times 8 \mathrm{~nm}^{2}$ ) and $\mathrm{ZnO}$ (spherical NPs; $24 \mathrm{~nm}$ ) on the bacterial communities present in the soil, and found that $\mathrm{ZnO}$ significantly impacted bacterial communities in a dose-dependent manner both in unplanted and planted soils, increasing Rhizobium and Sphingomonas, but decreasing Ensifer, Rhodospirillaceae, Clostridium and Azotobacter. The presence of soybean plants had different effects on soil bacterial communities affected by $\mathrm{ZnO}$. In planted soils, soybean decreased the impact of ZnO NPs on the bacterial communities as compared to the unplanted soils (50\% fewer sensitive bacterial operational taxonomic units), most probably by immobilizing the NPs via the root exudates, or by absorbing $\mathrm{Zn}$ ions via the roots, and therefore limiting the availability of $\mathrm{Zn}$ to soil bacteria [90]. Of note, $\mathrm{ZnO}$ was previously shown to have excellent antimicrobial properties [127]. Contrarily, $\mathrm{CeO}_{2}$ had little effect on the bacterial communities, except for the lowest concentration tested $(0.1 \mathrm{~g} / \mathrm{kg})$. In this case, $\mathrm{CeO}_{2}$ had a shifting effect on bacterial communities only in planted soils, which was attributed to the previously-reported detrimental effect on the plant root, where plants exposed to this concentration had significantly shorter roots than 
$\mathrm{CeO}_{2}$ NP-free controls [87]. The similarities between the two studies were also confirmed at higher concentrations, where the effects of $\mathrm{CeO}_{2}$ were minimal both on the microbial communities and the plant itself $[87,90]$.

While most of the aforementioned studies evaluated the effect on plant growth, a later study from the same groups aimed to evaluate the effects of $\mathrm{CeO}_{2}(8 \mathrm{~nm})$ and $\mathrm{ZnO} N P s(10 \mathrm{~nm})$ on the metabolism of the soybean in terms of chlorophyll production, protein content of seeds, ROS, lipid peroxidation and genotoxicity [91]. Both NPs had negative effects, but the most visible damage was seen for $\mathrm{CeO}_{2} \mathrm{NP}$ exposure: An increased ROS and lipid peroxidation and decreased total chlorophyll concentrations were more pronounced with medium $(0.5 \mathrm{~g} / \mathrm{kg}$ soil) and high ( $1.0 \mathrm{~g} / \mathrm{kg}$ soil) doses. These effects correlated well with leaf damage, lower pod and stem production, and a lower root nodule nitrogen fixation potential. Plant growth, yield and $\mathrm{N}_{2}$ fixation potential were not affected by $\mathrm{ZnO}$, but moderate oxidative stress, with slightly lower chlorophyll concentrations (attributable to $\mathrm{Zn}$ complexes) was observed in a dose-dependent manner. ROS levels were comparable to control, while some genotoxicity appeared in one plant exposed at the highest concentration tested of $\mathrm{ZnO}(0.5 \mathrm{~g} / \mathrm{kg}$ soil), mainly attributed to ionic $\mathrm{Zn}$ oxidative phytotoxicity [91].

The mild effects of $\mathrm{ZnO}$ on the soybean have been contradicted by the results from another study with plants cultivated in a standard soil microcosm (57-65 days), which has shown that ZnO $\mathrm{NPs}(<50 \mathrm{~nm})$ at 0.05 and $0.5 \mathrm{~g} / \mathrm{kg}$ soil affected significantly developmental stages and reproduction of the soybean plants: Roots were smaller, and no seeds were formed at the highest concentration $(0.5 \mathrm{~g} / \mathrm{kg})$ [92]. However, compared to the previous studies, the ZnO NPs in this study were larger by an order of magnitude, and their size might have influenced their biological effects, since the NPs properties are highly size-dependent $[30,53]$. While smaller $\mathrm{ZnO}$ particles were shown to dissolve in the soil and enter plant cells as $\mathrm{Zn}^{2+}$ cations, larger size particles could enter the cell compartments as NPs and have biologically different effects [128]. Higher dissolution rates would be expected for smaller sizes due to an increase in the surface specific area [77].

In another study, exposure to $\mathrm{CeO}_{2} \mathrm{NPs}(25 \mathrm{~nm})$ at $0.25-1 \mathrm{mg} / \mathrm{mL}$ did not significantly affect soybean seed germination or early development root length [95]. In plants grown hydroponically, Dan et al. [96] found dissolved Ce for the first time in plant seedling shoots exposed to $\mathrm{CeO}_{2} \mathrm{NPs}$. The impact on soybean was shown to be affected by the soil moisture content, with positive effects above $70 \%$ humidity $[97,98]$. In terms of interactions with other co-contaminants, $\mathrm{CeO}_{2}$ and $\mathrm{Cd}$ were found to interact significantly, affecting each other's accumulation, and consequently, their biological effects $[99,100]$. As expected, the effects were concentration-dependent [101], and soil sterilization was shown to have a significant impact on the effect of NPs, most probably due to the alterations of the soil microbiota [102].

In general, the above studies show that $\mathrm{ZnO}$ may have a positive effect at low concentrations $(50 \mathrm{mg} / \mathrm{kg}$ ) on the seed germination and early development (increased root length), with a promising potential against plant disease due to its antimicrobial properties. This observation was confirmed for many other terrestrial plants, as comprehensively summarized recently [129]. However, the effects are concentration-dependent, with negative outcomes in the high acute ranges ( $>500 \mathrm{mg} / \mathrm{kg})$, where an overproduction of ROS often leads to cytotoxicity, unless there is a deficiency of $\mathrm{Zn}$ in the growing media [129].

Most studies considered that the dissolution of $\mathrm{ZnO}$ to $\mathrm{Zn}$ ions plays the main role in the effects of these NPs on the soybean plants. As expected, dissolution was particle size-dependent, with smaller NPs being more susceptible to being solubilized. Proteins and organic substances can also increase the dissolution rates of $\mathrm{ZnO}$ through ligand-enhanced dissolution [128]. A very recent study with multiple plant crops has shown that soil $\mathrm{pH}$ and plant species were key factors affecting $\mathrm{ZnO}$ uptake and phytotoxicity [130]. Since many studies concur that $\mathrm{ZnO}$ toxicity can be mainly explained by the release of toxic ions, an important aspect needing further clarification in the nearest future is whether we should evaluate metal-containing NPs prone to dissolution using the existing legislation for heavy metals, or possibly include a correction for higher availability in agricultural soils. 
In terms of bioaccumulation in soybean plants, $\mathrm{ZnO}$ was distributed in all soybean plant organs, in a concentration-dependent manner. The presence of $\mathrm{Zn}$ in the edible parts of the exposed plants rises questions on possible transgenerational effects, trophic transfer and biomagnification [44]. So far, literature data on $\mathrm{ZnO}$ trophic transfer and biomagnification are limited [131]. One example assessing the trophic transfer of ZnO NPs $(30 \pm 17 \mathrm{~nm})$ from daphnids to zebrafish found a tenfold higher bioaccumulation compared to water exposure in other studies [132]. No studies have been found related to $\mathrm{ZnO}$ NP trophic transfer from plants to animals. Therefore, further research is needed to elucidate these aspects, especially since trophic transfer is a possible pathway for human exposure to ENMs [133].

Contrastingly to $\mathrm{ZnO}, \mathrm{CeO}_{2}$ was shown to be mainly present in the below ground parts of the soybean plant (root and nodules), and not to be prone to biotransformation. $\mathrm{CeO}_{2} \mathrm{NPs}$ are stable and insoluble in biological systems, and therefore they could be found in the roots of soybean as NPs. Both positive and negative effects were documented, $\mathrm{CeO}_{2}$ acting either as an antioxidant or as a ROS producer in soybean plants. In Brassica rapa, the responses to $\mathrm{CeO}_{2}$ exposure were also shown to vary with particle size and plant growth stages [134]. One study suggested possible transgenerational effects of $\mathrm{CeO}_{2}$, as a fraction of NPs was found in the seeds of the exposed plants [85].

Trophic transfer studies with $\mathrm{CeO}_{2} \mathrm{NPs}$ have shown that transfer and biomagnification of $\mathrm{Ce}$ occurs within the studied food chains [135-137].

\section{2. $\mathrm{TiO}_{2} \mathrm{NPs}$}

So far, the effects of $\mathrm{TiO}_{2}$ NPs on soybean are not as pronounced as those seen with $\mathrm{CeO}_{2}$ or $\mathrm{ZnO}[95,103-105]$. $\mathrm{TiO}_{2}$ had only marginal effects on seed germination [95], plant growth, nutrient content and the composition of bacterial communities within the rhizosphere [103,104]. However, in terms of co-contaminants, $\mathrm{TiO}_{2}$ was shown to restrict $\mathrm{Cd}$-induced plant toxicity (reduced plant growth and biomass, pigment and protein content) by increasing the photosynthetic rate and growth parameters of the plants [105]. Reducing the effect of dangerous co-contaminants may potentially be used for bioremediation of soil pollution $[61,138]$. Again, the $\mathrm{TiO}_{2} \mathrm{NP}$ diameter can play a significant role in uptake, accumulation and effects, as shown for many other NPs [30]. An experiment performed by Larue et al. [82] in wheat (Triticum aestivum) has shown that $\mathrm{TiO}_{2} \mathrm{NPs}<36 \mathrm{~nm}$ accumulated in roots and were distributed in the whole plant tissues, NPs 36-140 $\mathrm{nm}$ accumulated in the root parenchyma, but did not translocate to the shoots, and NPs $>140 \mathrm{~nm}$ did not accumulate in the roots. In all studies with soybean, the NP diameters were $<100 \mathrm{~nm}$, and were found in the plant roots, but with marginal effects on plant growth.

Many other studies in other plants, summarized in several reviews [10,13,57,61,62,139-141], have shown both positive (antimicrobial effect that can promote growth) and negative effects (oxidative stress, cytotoxicity, genotoxicity, reduced germination rates, reduced root and shoot growth and development). Compared to $\mathrm{ZnO}, \mathrm{TiO}_{2}$ translocation in plant tissues happened without the biotransformation or dissolution of NPs $[81,82]$. In a study with cucumber, Servin et al. showed that $\mathrm{TiO}_{2} \mathrm{NPs}_{\text {could }}$ enter food chains by translocation from root to fruit without biotransformation [142]. A similar result was obtained with tomatoes, when the plants were exposed at higher concentration of NPs (i.e., $130 \mathrm{mg} / \mathrm{kg}$ ) [143]. In a recent study evaluating trophic transfer, Chen et al. has shown that biomagnification factors of daphnia fed with algae exposed to $\mathrm{TiO}_{2}(1-10 \mathrm{mg} / \mathrm{L})$ were between 5.7 and 122 [144].

A very recent review has summarized the possible mechanisms of the toxicity of $\mathrm{TiO}_{2}$ to living organisms into three main categories [145]: (i) ROS via generation of photo-induced electron-hole pairs; (ii) electrostatic attachment (of positively-charged $\mathrm{TiO}_{2}$ ) to cell walls-causing wall damage and lipid peroxidation; and (iii) attachment to internal organelles (e.g., mitochondria) and macromolecules, post internalization. In our opinion, these three aspects may be the main mechanisms that can be attributed to most inert NMs up taken by living organisms (including plants). 


\subsection{Iron Oxides $\left(\mathrm{Fe}_{2} \mathrm{O}_{3}\right.$ and $\left.\mathrm{Fe}_{3} \mathrm{O}_{4}\right) \mathrm{NPS}$}

$\mathrm{Fe}_{2} \mathrm{O}_{3}$ NPs were shown to have mainly positive effects on soybean growth in terms of biomass increase [106], concentration-dependent protein, lipid, fatty acids and minerals [107], root elongation and shoot weight [108], chlorophyll content $[107,109]$ and an increased lignin content of roots [110]. In the last-mentioned study, however, the increased lignin content in roots caused a detrimental effect on plant growth [110]. $\mathrm{Fe}_{2} \mathrm{O}_{3} \mathrm{NPs}$ were applied via foliar spraying [106-108], medium [109,110] and soil amendment [108]. Alidoust and Isoda [108] showed that a foliar application of $\mathrm{Fe}_{2} \mathrm{O}_{3}(6 \mathrm{~nm} ; 0.05-2 \mathrm{~g} / \mathrm{L})$ gave better results in terms of photosynthesis efficiency than soil amendment. Additionally, increased stem and root growth and overall yield, were observed, and the effects were more pronounced than those observed with Fe in the ionic form (salts) [108]. Positive effects of iron oxide NPs were also seen in other plants [146]. The surface charge of the NPs of $\mathrm{Fe}_{3} \mathrm{O}_{4}$ had an important effect: Contrarily to the positively-charged NPs, negatively-charged NPs increased leaf P content, translocation of Fe to leaf tissues, and decreased the root colonization of rhizobia [104]. This suggests that the negatively-charged could increase biocompatibility and uptake of $\mathrm{Fe}_{3} \mathrm{O}_{4}$ NMs by plants [147].

\section{4. $\mathrm{CuONPS}$}

A similar effect in terms of increased lignin content in the root and a decrease in root growth as for $\mathrm{Fe}_{2} \mathrm{O}_{3}$ [110] was seen with $\mathrm{CuO}$ NPs $(50 \mathrm{~nm})$ [111]. The authors explained the effect by the increased activity levels of both cationic and anionic peroxidases [148]. In other studies in wheat, $\mathrm{CuO}$ was shown to be more toxic than $\mathrm{ZnO}$, and the toxicity was higher for smaller particle sizes $[75,76]$. This is not surprising, as it was shown that the release of ions through dissolution is the main mechanism by which $\mathrm{CuO}$ NPs cause oxidative stress, and that dissolution is more pronounced when the NPs are smaller [55]. The authors also showed that environmental factors from both the cultivation medium and the plants can influence the aggregation or dissolution of NPs, and therefore altering their effects on the plants $[75,76]$. In another study, CuO NPs were shown to induce DNA damage in agricultural and grassland plants [149]. A recent review summarized the interaction between CuO NPs and cultivated crop plants, and showed that the main toxic effects are caused by: (i) inhibition of seed germination (barley, cilantro, cucumber, lettuce, rice); (ii) decreases in root and shoot sizes (alfalfa, carrot, soybean, wheat, cotton); (iii) reduction of photosynthesis and respiration (maize, tomato); and (iv) morphological and enzymatic changes (rice, soybean, wheat) [55].

\section{5. $\mathrm{Cr}_{2} \mathrm{O}_{3} \mathrm{NPS}$}

A study with $\mathrm{Cr}_{2} \mathrm{O}_{3}$ NPs ( $30-50 \mathrm{~nm} ; 0.01-0.5 \mathrm{~g} / \mathrm{L}$ ) and soybean aimed to confirm if these NPs can be absorbed and translocated by plants; whether they may affect the chloroplasts and chlorophyll production [112]. The authors have shown that $\mathrm{Cr}_{2} \mathrm{O}_{3}$ NPs caused root swelling and decreased plant growth by lowering the activity of the photosynthetic enzymes (malate dehydrogenase and Ribulose-1,5-bisphosphate carboxylase/oxygenase-Rubisco), altering the substructure of chloroplasts, and reducing the formation and activity of chlorophyll, therefore inducing irreversible damage to the soybean plants.

\subsection{Ag NPs}

Ag NPs interaction with soybean was not shown to have a negative impact on germination and growth [115]. Ag reduced flooding stress by shifting from fermentation to normal cellular processes [114]; and reduced dichlorodiphenyldichloroethylene's (DDE; a co-contaminant) negative effects by lowering its accumulation rate [113]. However, in a very recent study with transgenic and non-transgenic soybean plants, Galazzi et al. [116] have shown that biomass production was reduced in the presence of Ag NPs, suggesting the presence of oxidative stress in the plants. Many studies in other plants have reflected both the positive and negative effects of Ag NPs on seed germination, and some were summarized in a relatively recent review [62]. Another very recent review has summarized 
the recent advances related to Ag NPs (synthesis, transformation in the environment and toxicity) [73]. In biological environments, Ag NPs can either dissolve, aggregate or adsorb at the surfaces, but also interact with other molecules (organic and inorganic), depending upon their size, medium $\mathrm{pH}$ and surface characteristics [73]. Aggregation induced by extracellular metal-binding polypeptides and proteins plays an important role in limiting NPs dispersion in natural environments [150]. It is well-known that Ag NPs can attach to sulfur proteins from bacterial membranes, enter bacterial cells and then attack the respiratory chain and cell division, finally leading to cell death [151-153]. This antimicrobial effect is another important mechanism that can possibly influence the plant root microbiota, which has a crucial role in the acquisition of nutrients from the soil [43].

\subsection{Carbon Nanotubes and Fullerenes}

Studies performed on soybean plant exposure to multi-walled carbon nanotubes (MWCNTs) and $\mathrm{C}_{60}$ fullerenes show both positive and negative influences. For example, Begum et al. found no signs of toxicity caused by MWCNTs exposure of soybean plant in hydroponic cultures [117], but observed decreases in the roots, shoots and biomass, as well as cell death and membrane damage in lettuce, red spinach, cucumber and rice-suggesting that the phytotoxicity effects are species-related.

Positive effects on the germination rate and growth of soybean seedlings upon MWCNTs exposure was documented by Lahiani et al. [118], with no observed negative effects on plant development. The study also reports an increased expression of genes encoding several types of water channel proteins. In a later hydroponic study, the same authors [119] showed that MWCNTs impacted the root growth in the soybean, diminishing both the fresh and dry weight of the roots, while no other negative effects were observed on the evolution of other plant organs. Positive effects observed include phenotypical changes and a stimulation of photosynthesis. Using Raman spectroscopy, MWCNTs were detected in roots, stem, leaves and seeds. The presence of CNTs in leaves and seeds raises again the issue of possible trophic transfer. Some studies published so far argue that the overall risk of trophic transfer is low for CNTs [154].

A relatively recent study found several inhibitory effects caused by MWCNTs exposure [120]. The total root length of seedlings was decreased by $29 \%$, and the formation of lateral roots and the shoot growth were also inhibited. Oxidative stress was induced; some antioxidants, e.g., proline and micronutrient supplementation ( $\mathrm{Zn}, \mathrm{Fe}, \mathrm{Mn}$ ) could revert the growth inhibition caused by exposure to MWCNTs. Zhai et al. [121] found that differently-charged MWCNTs (positive, neutral, negative) were accumulated by the soybean plant (roots, stems, leaves); the inhibition of transpiration and growth of dry weight biomass were reported for all types of nanotubes. They were transported from roots to specific locations in leaves, depending upon their charge and size. Although MWCNTs inhibited soybean growth, the same study showed a stimulation of maize growth, proving once again that the effects are dependent on the plant species [121].

In another study, exposure to either MWCNTs or $\mathrm{C}_{60}$-induced phytotoxicity in soil-cultivated plats [122]. MWCNTs reduced the biomass by $19.2-26.9 \%$ and the net growth by $29.8-31.9 \%$, and $\mathrm{C}_{60}$ fullerenes reduced the biomass by $25.0-40.4 \%$ and the net growth by $27.7-42.6 \%$. MWCNTs decreased the accumulation of pesticides chlordane and DDx (DDT and metabolites), and $\mathrm{C}_{60}$ increased chlordane accumulation. Exposure to $\mathrm{C}_{60}$ fullerenes resulted in oxidative stress, with cell membrane damage of roots and shoots. $\mathrm{C}_{60}$ lead to increase in the bioaccumulation of DDE, a persistent pollutant [123]. DDE shoot content was decreased by $48.0 \%$, but the root and whole plant levels were increased by $47.7 \%$ and $45.7 \%$, raising questions about potential risks on enhancing accumulation levels of soil contaminants.

The somehow contradicting results regarding the phytotoxicity of C-based materials on the same plant species can be due to the fact that in most of the above-mentioned studies, the toxicity was assessed on a macro level (germination and growth), and not in depth on a molecular level (cell morphology, metabolite production, genotoxicity). Sometimes, the toxic effects fail to influence the overall plant development (biomass, growth, germination), but can affect the plant genotype, 
metabolite production or can produce oxidative damage [155]. Moreover, C-based ENMs uptake was shown mainly in hydroponic studies, and was less frequently studied in soils. Bioavailability in soils and bioaccumulation in plants may be very different depending on soil type and organic matter content [154]. The strong affinity of CNTs for organic macromolecules in soils is well known [156].

\section{Plant Microbiota and the Influence of ENMs}

Understanding the plant-bacterial interaction mechanisms is crucial to elucidate the environmental changes impact on agriculture and for biotechnological applications to improve production in unfavorable environments. Plant-associated bacteria (microbiota) have an important ecological role in plant development, by promoting plant growth and productivity, and providing resistance to disease [157-159].

In terms of promoting plant growth, phosphorus $(\mathrm{P})$ uptake, one of the most important processes in plant nutrition, is increased by phosphate-solubilizing bacteria, which use inorganic phosphates applied to the soil as fertilizers [160,161]. Nitrogen fixation is another important process for plants where bacteria can have a crucial role [161-164]. $\mathrm{N}$ and $\mathrm{P}$ are key nutrients that limit agricultural sustainability around the globe [165]. In terms of protection against disease, bacteria can act as biocontrol agents against pathogenic bacteria and fungi, by competing effectively for colonization sites or nutrients, and by producing fungistatic compounds and bacterial allelochemicals [159,166].

Thus, the plant microbiota is involved in diverse biochemical mechanisms, as demonstrated by various studies about the bacterial influence on plant growth and health [43]. When present in soil, NPs can influence the plant microbiota, and especially the microbes associated with the root, with significant effects on plant growth. For soybean, this is the case for $\mathrm{ZnO}[87,90,92], \mathrm{CeO}_{2}$ [87] and $\mathrm{TiO}_{2}$ [104]. Some of these studies show that the effects could be selective, meaning that only some bacterial groups could be affected by certain NPs [167]. For example, Priester et al. [87] found that ZnO had relatively little effect on nitrogen-fixation bacteria, but $\mathrm{CeO}_{2}$ had practically shut down nitrogen fixation at high concentrations. NPs' influence on plant microbiota could be mainly a result of their antimicrobial properties, which are dependent upon size, surface reactivity and charge [127,151,152,168]. Soil type is also an important factor affecting the interaction between NPs and microbiota; organic matter present in the soil can interact with NPs and reduce their toxicity $[169,170]$.

When investigating CNTs' effects on root-associated microorganisms, the diversity of the soil microbiota was not influenced significantly in some cases [171,172]. In others, the effects were concentrationdependent [173], and differences were seen between functionalized and non-functionalized CNTs [172,173]. In other plants (e.g., tomato), the effects of CNTs were beneficial in terms of the amounts of flowers and fruits [171].

\section{Conclusions and Perspectives}

The current review paper summarized the data published in recent years (past two decades) about the impact of ENMs on soybean, a very important crop in terms of protein and oil production for human food. The interactions between soybean and ENMs were analyzed in terms of growth and production, influences on metabolism and on the plant-associated microbiota.

Several conclusions and outlooks can be drawn from the analyzed data:

(i) The interaction effects between edible plants (including soybean) and ENMs are materialdependent, in terms of NM type (organic vs inorganic), size, shape, surface charge, concentration, solubility and aggregation properties. Several toxicity mechanisms were identified when ENMs had a negative effect on plants: Overproduction of ROS and oxidative stress via uptake and accumulation in plant organs (especially in the roots), release of toxic ions (which can travel and accumulate faster than the parent NM), physical adhesion to biologic surfaces (e.g., protein corona around NPs) and influence on the root-associated microbiota (e.g., selective antimicrobial properties). Oxidative stress is ENM concentration-dependent, with high-dose exposures generating visible damage to the plant, while low-dose exposure (e.g., $<50 \mathrm{mg} / \mathrm{kg}$ of soil) may seem non-toxic, but with possible effects on the 
modulation of redox signaling inside cells [69]. Additionally, the ENM effect can vary depending on the application method, e.g., foliar spraying vs soil amendment.

(ii) The phytotoxicity of ENMs are species-related: The same ENM can have positive effects on one plant, be neutral for another, and impede growth and metabolism for a third. However, ENM uptake is common, and the documented presence of NMs in different plant organs and cells highlights the importance of detailed risk assessments of ENM-contaminated plants moving into the food chain. Moreover, the presence of ENMs in the edible parts of the plant raises questions on the possible risk of trophic transfer and biomagnification in animals and humans. Research studies tackling these aspects are scarce, and more research data are needed to clarify these important aspects, that may affect human health.

(iii) Many of the cited studies use ENM concentrations well above the actual levels in the soil and air (estimated in real-life conditions) and the toxic effects would need to be confirmed by studies with plants cultivated in real-life settings (i.e., in soils containing levels of ENMs close to reality). Moreover, more studies are needed related to long-term exposure, and the trans-generational impact of ENM accumulation in the seeds of the parent plant. Performing reliable bioaccumulation measurements will also be important in the future to enable new insights into the interaction mechanisms between plants and NMs of different types, shapes and sizes. New analytical methods, such as single-particle, inductively-coupled plasma mass spectroscopy, show promise to shed light on the size distribution of NMs in biological samples [174].

(iv) Soil represents the main pathway for ENM exposure to terrestrial plants, since the application of ENMs in the agricultural sector (i.e., herbicides, pesticides and fertilizers) has increased constantly over the past few decades. Soil type and composition are important factors in modeling the ENM nano-bio-interactions with plants (e.g., organic matter can bind to ENMs and decrease their transport in soil, and therefore possible toxicity). Future research data should also clarify the impact of surface-coated ENMs on plants, and consequently, on human health.

Particularly for soybean, the positive effects of ENMs in terms of germination and growth have been witnessed with the application of low concentrations of $\mathrm{ZnO}$ in soil $(50 \mathrm{mg} / \mathrm{kg}$ ), Fe oxides (both in soil and via foliar application), and sometimes with $\mathrm{CeO}_{2}, \mathrm{Ag}$ NPs and $\mathrm{CNTs}$ (under specific conditions). $\mathrm{TiO}_{2}$ was mainly neutral, while $\mathrm{CuO}$ and $\mathrm{Cr}_{2} \mathrm{O}_{3}$ exposures were detrimental for plant development. Many of the studies were however limited to the plant juvenile developmental stages (germination and seedlings), which limits the analysis of possible effects to plant organs still in development. There were several studies that evaluated the effect of some ENMs throughout the full life cycle of the plants, but more data are needed for a deeper understanding of possible effects. Additionally, future studies should clarify transgenerational effects and possible trophic transfer risks.

To summarize, we are at a stage where we started to be aware of the interconnection between the production and transport of NMs (natural, incidental and engineered), and their impact on our environment and life (plants, animals and humans). Therefore, multidisciplinary comprehensive risk-assessment studies should be carried out prior to the mass productions of potential hazardous materials, which may be otherwise innovative for energy and industrial purposes (e.g., the downside of plastic bioaccumulation and biotransformation in the environment). Moreover, legislation at local, national and international levels needs to keep up with the rapid evolution of the nanotechnology products and technologies.

Author Contributions: Conceptualization and supervision: V.C. and C.C.; writing, reviewing and editing: V.C., I.O., L.F.L., D.C.V., and C.C; funding acquisition: L.F.L., D.C.V. and C.C. All authors approved the final draft of the manuscript.

Funding: This work was supported by two Grants of Ministry of Research and Innovation, CNCS - UEFISCDI, project numbers PN-III-P1-1.2-PCCDI-2017-0056 and PN-III-P1-1.1-TE-2016-1907, within PNCDI III.

Conflicts of Interest: The authors declare no conflict of interest. 


\section{References}

1. Hochella, M.F., Jr.; Mogk, D.W.; Ranville, J.; Allen, I.C.; Luther, G.W.; Marr, L.C.; McGrail, B.P.; Murayama, M.; Qafoku, N.P.; Rosso, K.M.; et al. Natural, incidental, and engineered nanomaterials and their impacts on the Earth system. Science 2019, 363. [CrossRef] [PubMed]

2. Salata, O.V. Applications of nanoparticles in biology and medicine. J. Nanobiotechnol. 2004, 2. [CrossRef] [PubMed]

3. De Jong, W.H.; Borm, P.J.A. Drug delivery and nanoparticles: Applications and hazards. Int. J. Nanomed. 2008, 3, 133-149. [CrossRef]

4. Kamat, P.V. Photophysical, photochemical and photocatalytic aspects of metal nanoparticles. J. Phys. Chem. B 2002, 106, 7729-7744. [CrossRef]

5. Brigger, I.; Dubernet, C.; Couvreur, P. Nanoparticles in cancer therapy and diagnosis. Adv. Drug Del. Rev. 2002, 54, 631-651. [CrossRef]

6. Liu, R.; Lal, R. Potentials of engineered nanoparticles as fertilizers for increasing agronomic productions. Sci. Total Environ. 2015, 514, 131-139. [CrossRef] [PubMed]

7. Misra, P.; Shukla, P.K.; Pramanik, K.; Gautam, S.; Kole, C. Nanotechnology for crop improvement. In Plant Nanotechnology: Principles and Practices; Springer: Berlin, Germany, 2016; pp. 219-256.

8. Pelaez, M.; Nolan, N.T.; Pillai, S.C.; Seery, M.K.; Falaras, P.; Kontos, A.G.; Dunlop, P.S.M.; Hamilton, J.W.J.; Byrne, J.A.; O'Shea, K.; et al. A review on the visible light active titanium dioxide photocatalysts for environmental applications. Appl. Catal. B Environ. 2012, 125, 331-349. [CrossRef]

9. Keller, A.A.; Lazareva, A. Predicted Releases of Engineered Nanomaterials: From Global to Regional to Local. Environ. Sci. Technol. Lett. 2013, 1, 65-70. [CrossRef]

10. Rico, C.M.; Majumdar, S.; Duarte-Gardea, M.; Peralta-Videa, J.R.; Gardea-Torresdey, J.L. Interaction of nanoparticles with edible plants and their possible implications in the food chain. J. Agric. Food Chem. 2011, 59, 3485-3498. [CrossRef]

11. Bar-On, Y.M.; Phillips, R.; Milo, R. The biomass distribution on Earth. Proc. Natl. Acad. Sci. USA 2018, 115, 6506-6511. [CrossRef]

12. Nair, R.; Varghese, S.H.; Nair, B.G.; Maekawa, T.; Yoshida, Y.; Kumar, D.S. Nanoparticulate material delivery to plants. Plant Sci. 2010, 179, 154-163. [CrossRef]

13. Lv, J.; Christie, P.; Zhang, S. Uptake, translocation, and transformation of metal-based nanoparticles in plants: Recent advances and methodological challenges. Environ. Sci. Nano 2019, 6, 41-59. [CrossRef]

14. Ma, X.; Geiser-Lee, J.; Deng, Y.; Kolmakov, A. Interactions between engineered nanoparticles (ENPs) and plants: Phytotoxicity, uptake and accumulation. Sci. Total Environ. 2010, 408, 3053-3061. [CrossRef] [PubMed]

15. Schmutz, J.; Cannon, S.B.; Schlueter, J.; Ma, J.; Mitros, T.; Nelson, W.; Hyten, D.L.; Song, Q.; Thelen, J.J.; Cheng, J.; et al. Genome sequence of the palaeopolyploid soybean. Nature 2010, 463, 178-183. [CrossRef] [PubMed]

16. Klaine, S.J.; Alvarez, P.J.J.; Batley, G.E.; Fernandes, T.F.; Handy, R.D.; Lyon, D.Y.; Mahendra, S.; McLaughlin, M.J.; Lead, J.R. Nanomaterials in the environment: Behavior, fate, bioavailability, and effects. Environ. Toxicol. Chem. 2008, 27, 1825-1851. [CrossRef] [PubMed]

17. Liu, Y.; Zhou, G.; Liu, K.; Cui, Y. Design of Complex Nanomaterials for Energy Storage: Past Success and Future Opportunity. Acc. Chem. Res. 2017, 50, 2895-2905. [CrossRef] [PubMed]

18. Pourzahedi, L.; Pandorf, M.; Ravikumar, D.; Zimmerman, J.B.; Seager, T.P.; Theis, T.L.; Westerhoff, P.; Gilbertson, L.M.; Lowry, G.V. Life cycle considerations of nano-enabled agrochemicals: Are today's tools up to the task? Environ. Sci. Nano 2018, 5, 1057-1069. [CrossRef]

19. Vance, M.E.; Kuiken, T.; Vejerano, E.P.; McGinnis, S.P.; Hochella, M.F., Jr.; Hull, D.R. Nanotechnology in the real world: Redeveloping the nanomaterial consumer products inventory. Beilstein J. Nanotechnol. 2015, 6, 1769-1780. [CrossRef] [PubMed]

20. Keller, A.A.; McFerran, S.; Lazareva, A.; Suh, S. Global life cycle releases of engineered nanomaterials. J. Nanopart. Res. 2013, 15. [CrossRef]

21. Bundschuh, M.; Filser, J.; Lüderwald, S.; McKee, M.S.; Metreveli, G.; Schaumann, G.E.; Schulz, R.; Wagner, S. Nanoparticles in the environment: Where do we come from, where do we go to? Environ. Sci. Eur. 2018, 30. [CrossRef] [PubMed] 
22. Gottschalk, F.; Nowack, B. The release of engineered nanomaterials to the environment. J. Environ. Monit. 2011, 13, 1145-1155. [CrossRef] [PubMed]

23. Moore, M.N. Do nanoparticles present ecotoxicological risks for the health of the aquatic environment? Environ. Int. 2006, 32, 967-976. [CrossRef] [PubMed]

24. Borm, P.J.A.; Robbins, D.; Haubold, S.; Kuhlbusch, T.; Fissan, H.; Donaldson, K.; Schins, R.; Stone, V.; Kreyling, W.; Lademann, J.; et al. The potential risks of nanomaterials: A review carried out for ECETOC. Part. Fibre Toxicol. 2006, 3. [CrossRef] [PubMed]

25. Hoet, P.H.M.; Brüske-Hohlfeld, I.; Salata, O.V. Nanoparticles-Known and unknown health risks. J. Nanobiotechnol. 2004, 2. [CrossRef] [PubMed]

26. Mueller, N.C.; Nowack, B. Exposure modeling of engineered nanoparticles in the environment. Environ. Sci. Technol. 2008, 42, 4447-4453. [CrossRef] [PubMed]

27. Nowack, B.; Bucheli, T.D. Occurrence, behavior and effects of nanoparticles in the environment. Environ. Pollut. 2007, 150, 5-22. [CrossRef]

28. Lewinski, N.; Colvin, V.; Drezek, R. Cytotoxicity of nanopartides. Small 2008, 4, 26-49. [CrossRef]

29. Nel, A.; Xia, T.; Mädler, L.; Li, N. Toxic potential of materials at the nanolevel. Science 2006, 311, $622-627$. [CrossRef]

30. Jiang, W.; Kim, B.Y.S.; Rutka, J.T.; Chan, W.C.W. Nanoparticle-mediated cellular response is size-dependent. Nat. Nanotechnol. 2008, 3, 145-150. [CrossRef]

31. Cedervall, T.; Lynch, I.; Lindman, S.; Berggård, T.; Thulin, E.; Nilsson, H.; Dawson, K.A.; Linse, S. Understanding the nanoparticle-protein corona using methods to quntify exchange rates and affinities of proteins for nanoparticles. Proc. Natl. Acad. Sci. USA 2007, 104, 2050-2055. [CrossRef]

32. Verma, A.; Stellacci, F. Effect of surface properties on nanoparticle-cell interactions. Small 2010, 6, 12-21. [CrossRef] [PubMed]

33. Rizwan, M.; Ali, S.; Qayyum, M.F.; Ok, Y.S.; Adrees, M.; Ibrahim, M.; Zia-ur-Rehman, M.; Farid, M.; Abbas, F. Effect of metal and metal oxide nanoparticles on growth and physiology of globally important food crops: A critical review. J. Hazard. Mater. 2017, 322, 2-16. [CrossRef] [PubMed]

34. Oberdörster, G.; Oberdörster, E.; Oberdörster, J. Nanotoxicology: An emerging discipline evolving from studies of ultrafine particles. Environ. Health Perspect. 2005, 113, 823-839. [CrossRef] [PubMed]

35. López-Moreno, M.L.; Cassé, C.; Correa-Torres, S.N. Engineered NanoMaterials interactions with living plants: Benefits, hazards and regulatory policies. Curr. Opin. Environ. Sci. Health 2018, 6, 36-41. [CrossRef]

36. Zuverza-Mena, N.; Martínez-Fernández, D.; Du, W.; Hernandez-Viezcas, J.A.; Bonilla-Bird, N.; López-Moreno, M.L.; Komárek, M.; Peralta-Videa, J.R.; Gardea-Torresdey, J.L. Exposure of engineered nanomaterials to plants: Insights into the physiological and biochemical responses-A review. Plant Physiol. Biochem. 2017, 110, 236-264. [CrossRef]

37. Gottschalk, F.; Sonderer, T.; Scholz, R.W.; Nowack, B. Modeled environmental concentrations of engineered nanomaterials $\left(\mathrm{TiO}_{2}, \mathrm{ZnO}, \mathrm{Ag}, \mathrm{CNT}\right.$, fullerenes) for different regions. Environ. Sci. Technol. 2009, 43, 9216-9222. [CrossRef]

38. Batley, G.E.; Kirby, J.K.; McLaughlin, M.J. Fate and risks of nanomaterials in aquatic and terrestrial environments. Acc. Chem. Res. 2013, 46, 854-862. [CrossRef]

39. Brar, S.K.; Verma, M.; Tyagi, R.D.; Surampalli, R.Y. Engineered nanoparticles in wastewater and wastewater sludge-Evidence and impacts. Waste Manag. 2010, 30, 504-520. [CrossRef]

40. Lowry, G.V.; Gregory, K.B.; Apte, S.C.; Lead, J.R. Transformations of nanomaterials in the environment. Environ. Sci. Technol. 2012, 46, 6893-6899. [CrossRef]

41. Medina-Velo, I.A.; Peralta-Videa, J.R.; Gardea-Torresdey, J.L. Assessing plant uptake and transport mechanisms of engineered nanomaterials from soil. MRS Bull. 2017, 42, 379-383. [CrossRef]

42. Dimkpa, C.O. Soil properties influence the response of terrestrial plants to metallic nanoparticles exposure. Curr. Opin. Environ. Sci. Health 2018, 6, 1-8. [CrossRef]

43. Bulgarelli, D.; Schlaeppi, K.; Spaepen, S.; Van Themaat, E.V.L.; Schulze-Lefert, P. Structure and functions of the bacterial microbiota of plants. Annu. Rev. Plant Biol. 2013, 64, 807-838. [CrossRef] [PubMed]

44. Gardea-Torresdey, J.L.; Rico, C.M.; White, J.C. Trophic transfer, transformation, and impact of engineered nanomaterials in terrestrial environments. Environ. Sci. Technol. 2014, 48, 2526-2540. [CrossRef] [PubMed]

45. Wang, Q.; Ebbs, S.D.; Chen, Y.; Ma, X. Trans-generational impact of cerium oxide nanoparticles on tomato plants. Metallomics 2013, 5, 753-759. [CrossRef] [PubMed] 
46. Bouwmeester, H.; Dekkers, S.; Noordam, M.Y.; Hagens, W.I.; Bulder, A.S.; de Heer, C.; ten Voorde, S.E.C.G.; Wijnhoven, S.W.P.; Marvin, H.J.P.; Sips, A.J.A.M. Review of health safety aspects of nanotechnologies in food production. Regul. Toxicol. Pharmacol. 2009, 53, 52-62. [CrossRef] [PubMed]

47. Boxall, A.B.A.; Tiede, K.; Chaudhry, Q. Engineered nanomaterials in soils and water: How do they behave and could they pose a risk to human health? Nanomedicine 2007, 2, 919-927. [CrossRef] [PubMed]

48. Dobrovolskaia, M.A.; McNeil, S.E. Immunological properties of engineered nanomaterials. Nat. Nanotechnol. 2007, 2, 469-478. [CrossRef] [PubMed]

49. Siddiqi, K.S.; Husen, A. Plant Response to Engineered Metal Oxide Nanoparticles. Nanoscale Res. Lett. 2017, 12. [CrossRef] [PubMed]

50. Verma, S.K.; Das, A.K.; Patel, M.K.; Shah, A.; Kumar, V.; Gantait, S. Engineered nanomaterials for plant growth and development: A perspective analysis. Sci. Total Environ. 2018, 630, 1413-1435. [CrossRef]

51. Cota-Ruiz, K.; Delgado-Rios, M.; Martínez-Martínez, A.; Núñez-Gastelum, J.A.; Peralta-Videa, J.R.; Gardea-Torresdey, J.L. Current findings on terrestrial plants-Engineered nanomaterial interactions: Are plants capable of phytoremediating nanomaterials from soil? Curr. Opin. Environ. Sci. Health 2018, 6, 9-15. [CrossRef]

52. Jeevanandam, J.; Barhoum, A.; Chan, Y.S.; Dufresne, A.; Danquah, M.K. Review on nanoparticles and nanostructured materials: History, sources, toxicity and regulations. Beilstein J. Nanotechnol. 2018, 9, 1050-1074. [CrossRef]

53. Albanese, A.; Tang, P.S.; Chan, W.C.W. The effect of nanoparticle size, shape, and surface chemistry on biological systems. Annu. Rev. Biomed. Eng. 2012, 14, 1-16. [CrossRef]

54. Stampoulis, D.; Sinha, S.K.; White, J.C. Assay-dependent phytotoxicity of nanoparticles to plants. Environ. Sci. Technol. 2009, 43, 9473-9479. [CrossRef]

55. Rajput, V.D.; Minkina, T.; Suskova, S.; Mandzhieva, S.; Tsitsuashvili, V.; Chapligin, V.; Fedorenko, A. Effects of Copper Nanoparticles (CuO NPs) on Crop Plants: A Mini Review. BioNanoScience 2018, 8, 36-42. [CrossRef]

56. Van Aken, B. Gene expression changes in plants and microorganisms exposed to nanomaterials. Curr. Opin. Biotechnol. 2015, 33, 206-219. [CrossRef]

57. Du, W.; Tan, W.; Peralta-Videa, J.R.; Gardea-Torresdey, J.L.; Ji, R.; Yin, Y.; Guo, H. Interaction of metal oxide nanoparticles with higher terrestrial plants: Physiological and biochemical aspects. Plant Physiol. Biochem. 2017, 110, 210-225. [CrossRef]

58. Yanga, J.; Cao, W.; Rui, Y. Interactions between nanoparticles and plants: Phytotoxicity and defense mechanisms. J. Plant Interact. 2017, 12, 158-169. [CrossRef]

59. Reddy, P.V.L.; Hernandez-Viezcas, J.A.; Peralta-Videa, J.R.; Gardea-Torresdey, J.L. Lessons learned: Are engineered nanomaterials toxic to terrestrial plants? Sci. Total Environ. 2016, 568, 470-479. [CrossRef]

60. Ma, C.; White, J.C.; Dhankher, O.P.; Xing, B. Metal-Based Nanotoxicity and Detoxification Pathways in Higher Plants. Environ. Sci. Technol. 2015, 49, 7109-7122. [CrossRef]

61. Zhu, Y.; Xu, F.; Liu, Q.; Chen, M.; Liu, X.; Wang, Y.; Sun, Y.; Zhang, L. Nanomaterials and plants: Positive effects, toxicity and the remediation of metal and metalloid pollution in soil. Sci. Total Environ. 2019, 662, 414-421. [CrossRef]

62. Cox, A.; Venkatachalam, P.; Sahi, S.; Sharma, N. Silver and titanium dioxide nanoparticle toxicity in plants: A review of current research. Plant Physiol. Biochem. 2016, 107, 147-163. [CrossRef]

63. Miralles, P.; Church, T.L.; Harris, A.T. Toxicity, uptake, and translocation of engineered nanomaterials in vascular plants. Environ. Sci. Technol. 2012, 46, 9224-9239. [CrossRef]

64. Nel, A.E.; Mädler, L.; Velegol, D.; Xia, T.; Hoek, E.M.V.; Somasundaran, P.; Klaessig, F.; Castranova, V.; Thompson, M. Understanding biophysicochemical interactions at the nano-bio interface. Nat. Mater. 2009, 8, 543-557. [CrossRef]

65. Mittler, R. Oxidative stress, antioxidants and stress tolerance. Trends Plant Sci. 2002, 7, 405-410. [CrossRef]

66. Apel, K.; Hirt, H. Reactive oxygen species: Metabolism, oxidative stress, and signal transduction. Annu. Rev. Plant Biol. 2004, 55, 373-399. [CrossRef]

67. Gill, S.S.; Tuteja, N. Reactive oxygen species and antioxidant machinery in abiotic stress tolerance in crop plants. Plant Physiol. Biochem. 2010, 48, 909-930. [CrossRef]

68. Marslin, G.; Sheeba, C.J.; Franklin, G. Nanoparticles alter secondary metabolism in plants via ROS burst. Front. Plant Sci. 2017, 8. [CrossRef] 
69. Mendoza, R.P.; Brown, J.M. Engineered nanomaterials and oxidative stress: Current understanding and future challenges. Curr. Opin. Toxicol. 2019, 13, 74-80. [CrossRef]

70. Foyer, C.H.; Noctor, G. Oxidant and antioxidant signalling in plants: A re-evaluation of the concept of oxidative stress in a physiological context. Plant Cell Environ. 2005, 28, 1056-1071. [CrossRef]

71. Couturier, J.; Chibani, K.; Jacquot, J.P.; Rouhier, N. Cysteine-based redox regulation and signaling in plants. Front. Plant Sci. 2013, 4. [CrossRef]

72. Jones, D.P. Radical-free biology of oxidative stress. Am. J. Physiol. Cell Physiol. 2008, 295, C849-C868. [CrossRef] [PubMed]

73. Jorge de Souza, T.A.; Rosa Souza, L.R.; Franchi, L.P. Silver nanoparticles: An integrated view of green synthesis methods, transformation in the environment, and toxicity. Ecotoxicol. Environ. Saf. 2019, 171, 691-700. [CrossRef] [PubMed]

74. Hamilton, R.F., Jr.; Buckingham, S.; Holian, A. The effect of size on Ag nanosphere toxicity in macrophage cell models and lung epithelial cell lines is dependent on particle dissolution. Int. J. Mol. Sci. 2014, 15, 6815-6830. [CrossRef] [PubMed]

75. Dimkpa, C.O.; Latta, D.E.; McLean, J.E.; Britt, D.W.; Boyanov, M.I.; Anderson, A.J. Fate of CuO and ZnO nano- and microparticles in the plant environment. Environ. Sci. Technol. 2013, 47, 4734-4742. [CrossRef] [PubMed]

76. Dimkpa, C.O.; McLean, J.E.; Latta, D.E.; Manangón, E.; Britt, D.W.; Johnson, W.P.; Boyanov, M.I.; Anderson, A.J. $\mathrm{CuO}$ and $\mathrm{ZnO}$ nanoparticles: Phytotoxicity, metal speciation, and induction of oxidative stress in sand-grown wheat. J. Nanopart. Res. 2012, 14. [CrossRef]

77. Ma, H.; Williams, P.L.; Diamond, S.A. Ecotoxicity of manufactured ZnO nanoparticles-A review. Environ. Pollut. 2013, 172, 76-85. [CrossRef] [PubMed]

78. Lin, D.; Xing, B. Root uptake and phytotoxicity of ZnO nanoparticles. Environ. Sci. Technol. 2008, 42, 5580-5585. [CrossRef]

79. García-Gómez, C.; Obrador, A.; González, D.; Babín, M.; Fernández, M.D. Comparative effect of ZnO NPs, $\mathrm{ZnO}$ bulk and $\mathrm{ZnSO} 4$ in the antioxidant defences of two plant species growing in two agricultural soils under greenhouse conditions. Sci. Total Environ. 2017, 589, 11-24. [CrossRef]

80. Oberdörster, E.; Zhu, S.; Blickley, T.M.; McClellan-Green, P.; Haasch, M.L. Ecotoxicology of carbon-based engineered nanoparticles: Effects of fullerene (C60) on aquatic organisms. Carbon 2006, 44, 1112-1120. [CrossRef]

81. Servin, A.D.; Castillo-Michel, H.; Hernandez-Viezcas, J.A.; Diaz, B.C.; Peralta-Videa, J.R.; Gardea-Torresdey, J.L. Synchrotron micro-XRF and micro-XANES confirmation of the uptake and translocation of $\mathrm{TiO}_{2}$ nanoparticles in cucumber (Cucumis sativus) plants. Environ. Sci. Technol. 2012, 46, 7637-7643. [CrossRef]

82. Larue, C.; Laurette, J.; Herlin-Boime, N.; Khodja, H.; Fayard, B.; Flank, A.M.; Brisset, F.; Carriere, M. Accumulation, translocation and impact of $\mathrm{TiO}_{2}$ nanoparticles in wheat (Triticum aestivum spp.): Influence of diameter and crystal phase. Sci. Total Environ. 2012, 431, 197-208. [CrossRef] [PubMed]

83. Docter, D.; Westmeier, D.; Markiewicz, M.; Stolte, S.; Knauer, S.K.; Stauber, R.H. The nanoparticle biomolecule corona: Lessons learned-Challenge accepted? Chem. Soc. Rev. 2015, 44, 6094-6121. [CrossRef] [PubMed]

84. Asli, S.; Neumann, P.M. Colloidal suspensions of clay or titanium dioxide nanoparticles can inhibit leaf growth and transpiration via physical effects on root water transport. Plant Cell Environ. 2009, 32, 577-584. [CrossRef] [PubMed]

85. Zhu, H.; Han, J.; Xiao, J.Q.; Jin, Y. Uptake, translocation, and accumulation of manufactured iron oxide nanoparticles by pumpkin plants. J. Environ. Monit. 2008, 10, 713-717. [CrossRef] [PubMed]

86. López-Moreno, M.L.; De La Rosa, G.; Hernández-Viezcas, J.A.; Castillo-Michel, H.; Botez, C.E.; Peralta-Videa, J.R.; Gardea-Torresdey, J.L. Evidence of the differential biotransformation and genotoxicity of $\mathrm{ZnO}$ and $\mathrm{CeO} 2$ nanoparticles on soybean (Glycine max) plants. Environ. Sci. Technol. 2010, 44, 7315-7320. [CrossRef] [PubMed]

87. Priester, J.H.; Ge, Y.; Mielke, R.E.; Horst, A.M.; Moritz, S.C.; Espinosa, K.; Gelb, J.; Walker, S.L.; Nisbet, R.M.; An, Y.J.; et al. Soybean susceptibility to manufactured nanomaterials with evidence for food quality and soil fertility interruption. Proc. Natl. Acad. Sci. USA 2012, 109, E2451-E2456. [CrossRef] [PubMed]

88. Hernandez-Viezcas, J.A.; Castillo-Michel, H.; Andrews, J.C.; Cotte, M.; Rico, C.; Peralta-Videa, J.R.; Ge, Y.; Priester, J.H.; Holden, P.A.; Gardea-Torresdey, J.L. In Situ synchrotron X-ray fluorescence mapping and speciation of $\mathrm{CeO}_{2}$ and $\mathrm{ZnO}$ nanoparticles in soil cultivated soybean (Glycine max). ACS Nano 2013, 7, 1415-1423. [CrossRef] 
89. Peralta-Videa, J.R.; Hernandez-Viezcas, J.A.; Zhao, L.; Diaz, B.C.; Ge, Y.; Priester, J.H.; Holden, P.A.; Gardea-Torresdey, J.L. Cerium dioxide and zinc oxide nanoparticles alter the nutritional value of soil cultivated soybean plants. Plant Physiol. Biochem. 2014, 80, 128-135. [CrossRef]

90. Ge, Y.; Priester, J.H.; Van De Werfhorst, L.C.; Walker, S.L.; Nisbet, R.M.; An, Y.J.; Schimel, J.P.; Gardea-Torresdey, J.L.; Holden, P.A. Soybean plants modify metal oxide nanoparticle effects on soil bacterial communities. Environ. Sci. Technol. 2014, 48, 13489-13496. [CrossRef]

91. Priester, J.H.; Moritz, S.C.; Espinosa, K.; Ge, Y.; Wang, Y.; Nisbet, R.M.; Schimel, J.P.; Susana Goggi, A.; Gardea-Torresdey, J.L.; Holden, P.A. Damage assessment for soybean cultivated in soil with either CeO2 or $\mathrm{ZnO}$ manufactured nanomaterials. Sci. Total Environ. 2017, 579, 1756-1768. [CrossRef]

92. Yoon, S.J.; Kwak, J.I.; Lee, W.M.; Holden, P.A.; An, Y.J. Zinc oxide nanoparticles delay soybean development: A standard soil microcosm study. Ecotoxicol. Environ. Saf. 2014, 100, 131-137. [CrossRef]

93. Hoe, P.T.; Mai, N.C.; Lien, L.Q.; Ban, N.K.; Van Minh, C.; Chau, N.H.; Buu, N.Q.; Hien, D.T.; Van, N.T.; Hien, L.T.T.; et al. Germination responses of soybean seeds under $\mathrm{Fe}, \mathrm{ZnO}, \mathrm{Cu}$ and Co nanoparticle treatments. Int. J. Agric. Biol. 2018, 20, 1562-1568. [CrossRef]

94. Hashemi, S.; Asrar, Z.; Pourseyedi, S.; Nadernejad, N. Investigation of ZnO nanoparticles on proline, anthocyanin contents and photosynthetic pigments and lipid peroxidation in the soybean. IET Nanobiotechnol. 2019, 13, 66-70. [CrossRef]

95. Andersen, C.P.; King, G.; Plocher, M.; Storm, M.; Pokhrel, L.R.; Johnson, M.G.; Rygiewicz, P.T. Germination and early plant development of ten plant species exposed to titanium dioxide and cerium oxide nanoparticles. Environ. Toxicol. Chem. 2016, 35, 2223-2229. [CrossRef]

96. Dan, Y.; Ma, X.; Zhang, W.; Liu, K.; Stephan, C.; Shi, H. Single particle ICP-MS method development for the determination of plant uptake and accumulation of $\mathrm{CeO} 2$ nanoparticles. Anal. Bioanal. Chem. 2016, 408, 5157-5167. [CrossRef]

97. Cao, Z.; Stowers, C.; Rossi, L.; Zhang, W.; Lombardini, L.; Ma, X. Physiological effects of cerium oxide nanoparticles on the photosynthesis and water use efficiency of soybean (Glycine max (L.) Merr.). Environ. Sci. Nano 2017, 4, 1086-1094. [CrossRef]

98. Cao, Z.; Rossi, L.; Stowers, C.; Zhang, W.; Lombardini, L.; Ma, X. The impact of cerium oxide nanoparticles on the physiology of soybean (Glycine $\max$ (L.) Merr.) under different soil moisture conditions. Environ. Sci. Pollut. Res. 2018, 25, 930-939. [CrossRef]

99. Rossi, L.; Zhang, W.; Schwab, A.P.; Ma, X. Uptake, Accumulation, and in Planta Distribution of Coexisting Cerium Oxide Nanoparticles and Cadmium in Glycine max (L.) Merr. Environ. Sci. Technol. 2017, 51, 12815-12824. [CrossRef]

100. Rossi, L.; Sharifan, H.; Zhang, W.; Schwab, A.P.; Ma, X. Mutual effects and: In planta accumulation of co-existing cerium oxide nanoparticles and cadmium in hydroponically grown soybean (Glycine max (L.) Merr.). Environ. Sci. Nano 2018, 5, 150-157. [CrossRef]

101. Servin, A.D.; De la Torre-Roche, R.; Castillo-Michel, H.; Pagano, L.; Hawthorne, J.; Musante, C.; Pignatello, J.; Uchimiya, M.; White, J.C. Exposure of agricultural crops to nanoparticle $\mathrm{CeO} 2$ in biochar-amended soil. Plant Physiol. Biochem. 2017, 110, 147-157. [CrossRef]

102. Stowers, C.; King, M.; Rossi, L.; Zhang, W.; Arya, A.; Ma, X. Initial Sterilization of Soil Affected Interactions of Cerium Oxide Nanoparticles and Soybean Seedlings (Glycine max (L.) Merr.) in a Greenhouse Study. ACS Sustain. Chem. Eng. 2018, 6, 10307-10314. [CrossRef]

103. Burke, D.J.; Zhu, S.; Pablico-Lansigan, M.P.; Hewins, C.R.; Samia, A.C.S. Titanium oxide nanoparticle effects on composition of soil microbial communities and plant performance. Biol. Fertil. Soils 2014, 50. [CrossRef]

104. Burke, D.J.; Pietrasiak, N.; Situ, S.F.; Abenojar, E.C.; Porche, M.; Kraj, P.; Lakliang, Y.; Samia, A.C.S. Iron oxide and titanium dioxide nanoparticle effects on plant performance and root associated microbes. Int. J. Mol. Sci. 2015, 16, 23630-23650. [CrossRef]

105. Singh, J.; Lee, B.K. Influence of nano- $\mathrm{TiO}_{2}$ particles on the bioaccumulation of $\mathrm{Cd}$ in soybean plants (Glycine max): A possible mechanism for the removal of $\mathrm{Cd}$ from the contaminated soil. J. Environ. Manag. 2016, 170, 88-96. [CrossRef]

106. Sheykhbaglou, R.; Sedghi, M.; Tajbakhsh Shishevan, M.; Seyed Sharifi, R. Effects of Nano-Iron Oxide Particles on Agronomic Traits of Soybean. Not. Sci. Biol. 2010, 2, 112-113. [CrossRef] 
107. Sheykhbaglou, R.; Sedghi, M.; Fathi-Achachlouie, B. The effect of ferrous nano-oxide particles on physiological traits and nutritional compounds of soybean (Glycine max L.) seed. An. Acad. Bras. Cienc. 2018, 90, 485-494. [CrossRef]

108. Alidoust, D.; Isoda, A. Effect of $\gamma \mathrm{Fe} 2 \mathrm{O} 3$ nanoparticles on photosynthetic characteristic of soybean (Glycine max (L.) Merr.): Foliar spray versus soil amendment. Acta Physiol. Plant. 2013, 35, 3365-3375. [CrossRef]

109. Ghafariyan, M.H.; Malakouti, M.J.; Dadpour, M.R.; Stroeve, P.; Mahmoudi, M. Effects of magnetite nanoparticles on soybean chlorophyll. Environ. Sci. Technol. 2013, 47, 10645-10652. [CrossRef]

110. Cunha Lopes, T.L.; de Cássia Siqueira-Soares, R.; Gonçalves de Almeida, G.H.; Romano de Melo, G.S.; Barreto, G.E.; de Oliveira, D.M.; dos Santos, W.D.; Ferrarese-Filho, O.; Marchiosi, R. Lignin-induced growth inhibition in soybean exposed to iron oxide nanoparticles. Chemosphere 2018, 211, 226-234. [CrossRef]

111. Nair, P.M.G.; Chung, I.M. A Mechanistic Study on the Toxic Effect of Copper Oxide Nanoparticles in Soybean (Glycine max L.) Root Development and Lignification of Root Cells. Biol. Trace Elem. Res. 2014, 162, 342-352. [CrossRef]

112. Li, J.; Song, Y.; Wu, K.; Tao, Q.; Liang, Y.; Li, T. Effects of Cr2O3 nanoparticles on the chlorophyll fluorescence and chloroplast ultrastructure of soybean (Glycine max). Environ. Sci. Pollut. Res. 2018, 25, 19446-19457. [CrossRef] [PubMed]

113. De La Torre-Roche, R.; Hawthorne, J.; Musante, C.; Xing, B.; Newman, L.A.; Ma, X.; White, J.C. Impact of Ag nanoparticle exposure on $\mathrm{p}, \mathrm{p}^{\prime}$-DDE bioaccumulation by cucurbita pepo (Zucchini) and Glycine max (Soybean). Environ. Sci. Technol. 2013, 47, 718-725. [CrossRef] [PubMed]

114. Mustafa, G.; Sakata, K.; Hossain, Z.; Komatsu, S. Proteomic study on the effects of silver nanoparticles on soybean under flooding stress. J. Proteom. 2015, 122, 100-118. [CrossRef] [PubMed]

115. Guilger, M.; Pasquoto-Stigliani, T.; Bilesky-Jose, N.; Grillo, R.; Abhilash, P.C.; Fraceto, L.F.; De Lima, R. Biogenic silver nanoparticles based on trichoderma harzianum: Synthesis, characterization, toxicity evaluation and biological activity. Sci. Rep. 2017, 7. [CrossRef] [PubMed]

116. Galazzi, R.M.; Lopes Júnior, C.A.; de Lima, T.B.; Gozzo, F.C.; Arruda, M.A.Z. Evaluation of some effects on plant metabolism through proteins and enzymes in transgenic and non-transgenic soybeans after cultivation with silver nanoparticles. J. Proteom. 2019, 191, 88-106. [CrossRef]

117. Begum, P.; Ikhtiari, R.; Fugetsu, B.; Matsuoka, M.; Akasaka, T.; Watari, F. Phytotoxicity of multi-walled carbon nanotubes assessed by selected plant species in the seedling stage. Appl. Surf. Sci. 2012, 262, 120-124. [CrossRef]

118. Lahiani, M.H.; Dervishi, E.; Chen, J.; Nima, Z.; Gaume, A.; Biris, A.S.; Khodakovskaya, M.V. Impact of carbon nanotube exposure to seeds of valuable crops. ACS Appl. Mater. Interfaces 2013, 5, 7965-7973. [CrossRef]

119. Lahiani, M.H.; Nima, Z.A.; Villagarcia, H.; Biris, A.S.; Khodakovskaya, M.V. Assessment of Effects of the Long-Term Exposure of Agricultural Crops to Carbon Nanotubes. J. Agric. Food Chem. 2018, 66, 6654-6662. [CrossRef]

120. Zaytseva, O.; Wang, Z.; Neumann, G. Phytotoxicity of carbon nanotubes in soybean as determined by interactions with micronutrients. J. Nanopart. Res. 2017, 19. [CrossRef]

121. Zhai, G.; Gutowski, S.M.; Walters, K.S.; Yan, B.; Schnoor, J.L. Charge, Size, and Cellular Selectivity for Multiwall Carbon Nanotubes by Maize and Soybean. Environ. Sci. Technol. 2015, 49, 7380-7390. [CrossRef]

122. De La Torre-Roche, R.; Hawthorne, J.; Deng, Y.; Xing, B.; Cai, W.; Newman, L.A.; Wang, Q.; Ma, X.; Hamdi, H.; White, J.C. Multiwalled carbon nanotubes and C60 fullerenes differentially impact the accumulation of weathered pesticides in four agricultural plants. Environ. Sci. Technol. 2013, 47, 12539-12547. [CrossRef] [PubMed]

123. De La Torre-Roche, R.; Hawthorne, J.; Deng, Y.; Xing, B.; Cai, W.; Newman, L.A.; Wang, C.; Ma, X.; White, J.C. Fullerene-enhanced accumulation of p, p'-DDE in agricultural crop species. Environ. Sci. Technol. 2012, 46, 9315-9323. [CrossRef] [PubMed]

124. Lv, J.; Zhang, S.; Luo, L.; Han, W.; Zhang, J.; Yang, K.; Christie, P. Dissolution and microstructural transformation of $\mathrm{ZnO}$ nanoparticles under the influence of phosphate. Environ. Sci. Technol. 2012, 46, 7215-7221. [CrossRef] [PubMed]

125. Wang, Y.; Nowack, B. Dynamic probabilistic material flow analysis of nano-SiO2, nano iron oxides, nano-CeO2, nano-Al2O3, and quantum dots in seven European regions. Environ. Pollut. 2018, 235, 589-601. [CrossRef] [PubMed] 
126. Shute, T.; Macfie, S.M. Cadmium and zinc accumulation in soybean: A threat to food safety? Sci. Total Environ. 2006, 371, 63-73. [CrossRef] [PubMed]

127. Azam, A.; Ahmed, A.S.; Oves, M.; Khan, M.S.; Habib, S.S.; Memic, A. Antimicrobial activity of metal oxide nanoparticles against Gram-positive and Gram-negative bacteria: A comparative study. Int. J. Nanomed. 2012, 7, 6003-6009. [CrossRef] [PubMed]

128. Xia, T.; Kovochich, M.; Liong, M.; Mädler, L.; Gilbert, B.; Shi, H.; Yeh, J.I.; Zink, J.I.; Nel, A.E. Comparison of the mechanism of toxicity of zinc oxide and cerium oxide nanoparticles based on dissolution and oxidative stress properties. ACS Nano 2008, 2, 2121-2134. [CrossRef] [PubMed]

129. Reddy Pullagurala, V.L.; Adisa, I.O.; Rawat, S.; Kim, B.; Barrios, A.C.; Medina-Velo, I.A.; Hernandez-Viezcas, J.A.; Peralta-Videa, J.R.; Gardea-Torresdey, J.L. Finding the conditions for the beneficial use of ZnO nanoparticles towards plants-A review. Environ. Pollut. 2018, 241, 1175-1181. [CrossRef] [PubMed]

130. García-Gómez, C.; Obrador, A.; González, D.; Babín, M.; Fernández, M.D. Comparative study of the phytotoxicity of $\mathrm{ZnO}$ nanoparticles and $\mathrm{Zn}$ accumulation in nine crops grown in a calcareous soil and an acidic soil. Sci. Total Environ. 2018, 644, 770-780. [CrossRef] [PubMed]

131. Tangaa, S.R.; Selck, H.; Winther-Nielsen, M.; Khan, F.R. Trophic transfer of metal-based nanoparticles in aquatic environments: A review and recommendations for future research focus. Environ. Sci. Nano 2016, 3, 966-981. [CrossRef]

132. Skjolding, L.M.; Winther-Nielsen, M.; Baun, A. Trophic transfer of differently functionalized zinc oxide nanoparticles from crustaceans (Daphnia magna) to zebrafish (Danio rerio). Aquat. Toxicol. 2014, 157, 101-108. [CrossRef] [PubMed]

133. Karimi, M.; Sadeghi, R.; Kokini, J. Human exposure to nanoparticles through trophic transfer and the biosafety concerns that nanoparticle-contaminated foods pose to consumers. Trends Food Sci. Technol. 2018, 75, 129-145. [CrossRef]

134. Ma, X.; Wang, Q.; Rossi, L.; Zhang, W. Cerium Oxide Nanoparticles and Bulk Cerium Oxide Leading to Different Physiological and Biochemical Responses in Brassica rapa. Environ. Sci. Technol. 2016, 50, 6793-6802. [CrossRef] [PubMed]

135. Hawthorne, J.; De La Torre Roche, R.; Xing, B.; Newman, L.A.; Ma, X.; Majumdar, S.; Gardea-Torresdey, J.; White, J.C. Particle-size dependent accumulation and trophic transfer of cerium oxide through a terrestrial food chain. Environ. Sci. Technol. 2014, 48, 13102-13109. [CrossRef] [PubMed]

136. Ma, Y.; Yao, Y.; Yang, J.; He, X.; Ding, Y.; Zhang, P.; Zhang, J.; Wang, G.; Xie, C.; Luo, W.; et al. Trophic Transfer and Transformation of $\mathrm{CeO} 2$ Nanoparticles along a Terrestrial Food Chain: Influence of Exposure Routes. Environ. Sci. Technol. 2018, 52, 7921-7927. [CrossRef] [PubMed]

137. Majumdar, S.; Trujillo-Reyes, J.; Hernandez-Viezcas, J.A.; White, J.C.; Peralta-Videa, J.R.; Gardea-Torresdey, J.L. Cerium Biomagnification in a Terrestrial Food Chain: Influence of Particle Size and Growth Stage. Environ. Sci. Technol. 2016, 50, 6782-6792. [CrossRef] [PubMed]

138. Peralta-Videa, J.R.; Zhao, L.; Lopez-Moreno, M.L.; de la Rosa, G.; Hong, J.; Gardea-Torresdey, J.L. Nanomaterials and the environment: A review for the biennium 2008-2010. J. Hazard. Mater. 2011, 186, 1-15. [CrossRef] [PubMed]

139. Aslani, F.; Bagheri, S.; Muhd Julkapli, N.; Juraimi, A.S.; Hashemi, F.S.G.; Baghdadi, A. Effects of engineered nanomaterials on plants growth: An overview. Sci. World J. 2014, 2014. [CrossRef] [PubMed]

140. Chichiriccò, G.; Poma, A. Penetration and toxicity of nanomaterials in higher plants. Nanomaterials 2015, 5, 851-873. [CrossRef] [PubMed]

141. Tan, W.; Peralta-Videa, J.R.; Gardea-Torresdey, J.L. Interaction of titanium dioxide nanoparticles with soil components and plants: Current knowledge and future research needs-a critical review. Environ. Sci. Nano 2018, 5, 257-278. [CrossRef]

142. Servin, A.D.; Morales, M.I.; Castillo-Michel, H.; Hernandez-Viezcas, J.A.; Munoz, B.; Zhao, L.; Nunez, J.E.; Peralta-Videa, J.R.; Gardea-Torresdey, J.L. Synchrotron verification of $\mathrm{TiO}_{2}$ accumulation in cucumber fruit: A possible pathway of $\mathrm{TiO}_{2}$ nanoparticle transfer from soil into the food chain. Environ. Sci. Technol. 2013, 47, 11592-11598. [CrossRef] [PubMed]

143. Wang, Q.; Ma, X.; Zhang, W.; Pei, H.; Chen, Y. The impact of cerium oxide nanoparticles on tomato (Solanum lycopersicum L.) and its implications for food safety. Metallomics 2012, 4, 1105-1112. [CrossRef] [PubMed]

144. Chen, X.; Zhu, Y.; Yang, K.; Zhu, L.; Lin, D. Nanoparticle TiO 2 size and rutile content impact bioconcentration and biomagnification from algae to daphnia. Environ. Pollut. 2019. [CrossRef] 
145. Hou, J.; Wang, L.; Wang, C.; Zhang, S.; Liu, H.; Li, S.; Wang, X. Toxicity and mechanisms of action of titanium dioxide nanoparticles in living organisms. J. Environ. Sci. 2019, 75, 40-53. [CrossRef] [PubMed]

146. Ruttkay-Nedecky, B.; Krystofova, O.; Nejdl, L.; Adam, V. Nanoparticles based on essential metals and their phytotoxicity. J. Nanobiotechnol. 2017, 15. [CrossRef] [PubMed]

147. Liu, Y.; Yue, L.; Wang, Z.; Xing, B. Processes and mechanisms of photosynthesis augmented by engineered nanomaterials. Environ. Chem. 2019. [CrossRef]

148. Lin, C.C.; Chen, L.M.; Liu, Z.H. Rapid effect of copper on lignin biosynthesis in soybean roots. Plant Sci. 2005, 168, 855-861. [CrossRef]

149. Atha, D.H.; Wang, H.; Petersen, E.J.; Cleveland, D.; Holbrook, R.D.; Jaruga, P.; Dizdaroglu, M.; Xing, B.; Nelson, B.C. Copper oxide nanoparticle mediated DNA damage in terrestrial plant models. Environ. Sci. Technol. 2012, 46, 1819-1827. [CrossRef]

150. Moreau, J.W.; Weber, P.K.; Martin, M.C.; Gilbert, B.; Hutcheon, I.D.; Banfield, J.F. Extracellular proteins limit the dispersal of biogenic nanoparticles. Science 2007, 316, 1600-1603. [CrossRef]

151. Morones, J.R.; Elechiguerra, J.L.; Camacho, A.; Holt, K.; Kouri, J.B.; Ramírez, J.T.; Yacaman, M.J. The bactericidal effect of silver nanoparticles. Nanotechnology 2005, 16, 2346-2353. [CrossRef]

152. Rai, M.; Yadav, A.; Gade, A. Silver nanoparticles as a new generation of antimicrobials. Biotechnol. Adv. 2009, 27, 76-83. [CrossRef] [PubMed]

153. Sharma, V.K.; Yngard, R.A.; Lin, Y. Silver nanoparticles: Green synthesis and their antimicrobial activities. Adv. Colloid Interface Sci. 2009, 145, 83-96. [CrossRef]

154. Bjorkland, R.; Tobias, D.A.; Petersen, E.J. Increasing evidence indicates low bioaccumulation of carbon nanotubes. Environ. Sci. Nano 2017, 4, 747-766. [CrossRef] [PubMed]

155. Verma, S.K.; Das, A.K.; Gantait, S.; Kumar, V.; Gurel, E. Applications of carbon nanomaterials in the plant system: A perspective view on the pros and cons. Sci. Total Environ. 2019, 667, 485-499. [CrossRef] [PubMed]

156. Zhao, Q.; Petersen, E.J.; Cornelis, G.; Wang, X.; Guo, X.; Tao, S.; Xing, B. Retention of 14C-labeled multiwall carbon nanotubes by humic acid and polymers: Roles of macromolecule properties. Carbon 2016, 99, $229-237$. [CrossRef] [PubMed]

157. Sturz, A.V.; Christie, B.R.; Nowak, J. Bacterial endophytes: Potential role in developing sustainable systems of crop production. Crit. Rev. Plant Sci. 2000, 19, 1-30. [CrossRef]

158. Hayat, R.; Ali, S.; Amara, U.; Khalid, R.; Ahmed, I. Soil beneficial bacteria and their role in plant growth promotion: A review. Ann. Microbiol. 2010, 60, 579-598. [CrossRef]

159. Compant, S.; Duffy, B.; Nowak, J.; Clément, C.; Barka, E.A. Use of plant growth-promoting bacteria for biocontrol of plant diseases: Principles, mechanisms of action, and future prospects. Appl. Environ. Microbiol. 2005, 71, 4951-4959. [CrossRef]

160. Rodríguez, H.; Fraga, R. Phosphate solubilizing bacteria and their role in plant growth promotion. Biotechnol. Adv. 1999, 17, 319-339. [CrossRef]

161. Richardson, A.E.; Barea, J.M.; McNeill, A.M.; Prigent-Combaret, C. Acquisition of phosphorus and nitrogen in the rhizosphere and plant growth promotion by microorganisms. Plant Soil 2009, 321, 305-339. [CrossRef]

162. Vance, C.P. Symbiotic nitrogen fixation and phosphorus acquisition. Plant nutrition in a world of declining renewable resources. Plant Physiol. 2001, 127, 390-397. [CrossRef] [PubMed]

163. Vessey, J.K. Plant growth promoting rhizobacteria as biofertilizers. Plant Soil 2003, 255, 571-586. [CrossRef]

164. Johansson, J.F.; Paul, L.R.; Finlay, R.D. Microbial interactions in the mycorrhizosphere and their significance for sustainable agriculture. FEMS Microbiol. Ecol. 2004, 48, 1-13. [CrossRef] [PubMed]

165. Tilman, D.; Cassman, K.G.; Matson, P.A.; Naylor, R.; Polasky, S. Agricultural sustainability and intensive production practices. Nature 2002, 418, 671-677. [CrossRef] [PubMed]

166. Bonfante, P.; Anca, I.A. Plants, mycorrhizal fungi, and bacteria: A network of interactions. Annu. Rev. Microbiol. 2009, 63, 363-383. [CrossRef] [PubMed]

167. Ge, Y.; Schimel, J.P.; Holdena, P.A. Identification of soil bacteria susceptible to $\mathrm{TiO}_{2}$ and $\mathrm{ZnO}$ nanoparticles. Appl. Environ. Microbiol. 2012, 78, 6749-6758. [CrossRef] [PubMed]

168. Stoimenov, P.K.; Klinger, R.L.; Marchin, G.L.; Klabunde, K.J. Metal oxide nanoparticles as bactericidal agents. Langmuir 2002, 18, 6679-6686. [CrossRef]

169. Frenk, S.; Ben-Moshe, T.; Dror, I.; Berkowitz, B.; Minz, D. Effect of metal oxide nanoparticles on microbial community structure and function in two different soil types. PLoS ONE 2013, 8. [CrossRef] [PubMed] 
170. Rousk, J.; Ackermann, K.; Curling, S.F.; Jones, D.L. Comparative toxicity of nanoparticulate CuO and ZnO to soil bacterial communities. PLOS ONE 2012, 7. [CrossRef]

171. Khodakovskaya, M.V.; Kim, B.S.; Kim, J.N.; Alimohammadi, M.; Dervishi, E.; Mustafa, T.; Cernigla, C.E. Carbon nanotubes as plant growth regulators: Effects on tomato growth, reproductive system, and soil microbial community. Small 2013, 9, 115-123. [CrossRef]

172. Kerfahi, D.; Tripathi, B.M.; Singh, D.; Kim, H.; Lee, S.; Lee, J.; Adams, J.M. Effects of functionalized and raw multi-walled carbon nanotubes on soil bacterial community composition. PLoS ONE 2015, 10, e0123042. [CrossRef] [PubMed]

173. Liné, C.; Larue, C.; Flahaut, E. Carbon nanotubes: Impacts and behaviour in the terrestrial ecosystem-A review. Carbon 2017, 123, 767-785. [CrossRef]

174. Deng, Y.; Petersen, E.J.; Challis, K.E.; Rabb, S.A.; Holbrook, R.D.; Ranville, J.F.; Nelson, B.C.; Xing, B. Multiple Method Analysis of $\mathrm{TiO}_{2}$ Nanoparticle Uptake in Rice (Oryza sativa L.) Plants. Environ. Sci. Technol. 2017, 51, 10615-10623. [CrossRef] [PubMed]

(C) 2019 by the authors. Licensee MDPI, Basel, Switzerland. This article is an open access article distributed under the terms and conditions of the Creative Commons Attribution (CC BY) license (http://creativecommons.org/licenses/by/4.0/). 